\title{
Spatial distribution and source identification of heavy metal pollution in roadside surface soil: a study of Dhaka Aricha highway, Bangladesh
}

Fahad Ahmed', A. N. M. Fakhruddin', M. D. Toufick Imam', Nasima Khan², Tanzir Ahmed Khan², Md. Mahfuzur Rahman² and Abu Tareq Mohammad Abdullah ${ }^{2^{*}}$

\begin{abstract}
Introduction: In this study, metal pollution and their sources in surface soils were evaluated by pollution indices and multivariate statistical techniques in association with a geographical information system (GIS).

Methods: Surface soil samples were collected in dry season from different locations of Dhaka Aricha highway and analyzed by energy dispersive $X$-ray fluorescence (EDXRF).

Results: Thirteen different metals were found in the tested samples. Pollution indices are determined by enrichment factor in an order of $\mathrm{Zr}>\mathrm{Sn}>\mathrm{P}>\mathrm{Mn}>\mathrm{Zn}>\mathrm{Rb}>\mathrm{Fe}>\mathrm{Ba}>\mathrm{Sr}>\mathrm{Ti}>\mathrm{K}>\mathrm{Ca}>\mathrm{Al}$. The resulting geoaccumulation index $\left(\mathrm{I}_{\text {geo }}\right)$ value shows the following order: $\mathrm{Sn}>\mathrm{Zr}>\mathrm{P}>\mathrm{Mn}>\mathrm{Zn}>\mathrm{Rb}>\mathrm{Fe}>\mathrm{Ba}>\mathrm{Ti}>\mathrm{Sr}>\mathrm{K}>\mathrm{Ca}>\mathrm{Al}$. Contamination factors (CFs) of the metals range from 1.422 to 3.979 (Fe); 0.213 to 1.089 (Al); 0.489 to 3.484 (Ca); 1.496 to 2.372 (K); 1.287 to 3.870 (Ti); 2.200 to 14.588 (Mn); 5.938 to 56.750 (Zr); 0.980 to 3.500 (Sr); 2.321 to 4.857 (Rb); 2.737 to 6.526 (Zn); 16.667 to 27.333 (Sn); 3.157 to $16.286(\mathrm{P})$; and 0.741 to 3.328 (Ba). Pollution load index calculated from the CFs indicates that soils are strongly contaminated by Zr and Sn. Principal component analysis (PCA) of parameters exhibits three major components. R-mode cluster analysis reveals three distinct groups in both site and metal basis clustering that shows a similar pattern with the PCA.
\end{abstract}

Conclusions: These results might be helpful for future monitoring of further increase of heavy metal concentrations in surface soils along highways.

Keywords: Heavy metals, Geoaccumulation index (Igeo), Contamination factor (CF), Pollution load index (PLI), Principal component analysis (PCA), Dhaka Aricha highway

\section{Introduction}

Rapid urbanization and industrialization in Bangladesh leads to economic growth and gives the chance of thinking of being a developed country in the future; on the other side, this process changes the whole environment drastically. Our planet, or in a small sense the environment, has the capability to minimize the adverse effects, but now, it is alarming for us to think about it. Dhaka, a megacity in the world, is in the worst situation in terms

\footnotetext{
* Correspondence: tareq_dubd@yahoo.com

${ }^{2}$ Institute of Food Science \& Technology (IFST), Bangladesh Council of

Scientific \& Industrial Research (BCSIR), Dhaka, Bangladesh

Full list of author information is available at the end of the article
}

of environmental perspective. Environmental pollution has crossed its line, degrading the whole environment day by day. High population and large density of vehicle emissions are industrial pollutions that are circulated everywhere, the main culprits to degrade the system (Chowdhury 2006; Islam 2014). The situation is worst in the transition point of the city like bus stands. The major highway like Dhaka Aricha highway is being polluted for vehicle emissions, an industrial pollution that causes the disturbance of the environment. Heavy metal contamination of aquatic ecosystems has received much attention because of its toxicity, abundance, and persistence (Arnason and Fletcher 2003). Elevated levels of

\section{Springer}


heavy metals in environmental compartments, such as aquatic soils, may pose a risk to human health due to their transfer in aquatic media and uptake by living organisms, thereby entering the food chain (Sin et al. 2001; Varol and Sen 2012). Soils are ecologically sensitive components of the aquatic ecosystems and are also a reservoir of the contaminants, which take part considerably in maintaining the trophic status for any water reservoir (Singh et al. 2005a, b).

Roads play a major role in stimulating social and economic progress, and road construction has also resulted in heavy environment pollution in this region (Liu et al. 2006). Road traffic is an important deleterious factor concerning air quality, noise, and land consumption (Zechmeister et al. 2005). The contribution of cars and road transports to the global emission of atmospheric pollutants is regularly increasing (Viard et al. 2004). The road transports also induce the contamination of nearer soils by a pollutant transfer via the atmospheric fallouts (Viard et al. 2004; Nabuloa et al. 2006) or road runoff (Mitsch and Gosselink 1993; Nabuloa et al. 2006). Maximum researchers have stated the influence of the traffic load on heavy metal contents in topsoils and their variability with distance (Ward et al. 1977; Rodriguez and Rodriguez 1982; Garcia and Milla'n 1998; Zhang et al. 1999; Turer and Maynard 2003). Nabuloa et al. (2006) also showed total trace metal concentrations in roadside soils decreased exponentially with increasing distance from roadways. Although the concentrations of metals in the roadside soil were influenced by meteorological conditions (Othman et al. 1997; Sezgin et al. 2003), traffic density (Garcia and Milla'n 1998; Nabuloa et al. 2006), the kind of vehicle in traffic (Sezgin et al. 2003; Nabuloa et al. 2006), and soil parameters (Viard et al. 2004) were also verified in some studies; little information was known about the heavy metal accumulation in roadside soils along the roads with different transportation periods.

Dhaka Aricha highway plays a vital role in interdistrict and inter-regional transports as it links the northwestern and northern region of Bangladesh with Dhaka. It originates from Amin Bazar Bridge and ends at Aricha Ghat, covering a length of $75.4 \mathrm{~km}$ (Hoque et al. 2007). Huge vehicle loads and industrial activities make a pollutant hotspot zone around these highway areas. Emissions from high transportation density disperse around the agricultural field, water body, and livestock areas which are alongside the highway areas. Huge contamination loads especially heavy metals accumulate in the biotic components and enter into the food chain. Concentration of these heavy metals in soils is associated with geometrical cycles and biological processes and could be greatly influenced by high traffic load and transportation activities. In the food chain, primary producers, i.e., plants, are capable of absorbing these metals from the soil (Kakulu and Abdullahi 2004; Rajaram and Das 2008). These metals each contaminate into the soil when they undergo chemical reactions and could come in direct contact with roots of plants (Udosen et al. 1990). When these plants in the form of vegetables are consumed by man, trace metals become bioaccumulated and eventually result in several ailments which may subsequently cause death (Odiette 1999). In some cases, plants accumulate some of these metals which are not injurious to them but may be poisonous to animals grazing on the plants (Raven and Evert 1976). Nabuloa et al. (2006) reported that leaves of roadside crops can accumulate trace metals at high concentrations, causing a serious health risk to consumers.

Monitoring of anthropogenic release of heavy metals is usually done to determine the distribution of pollutants and apportionment of sources (Kelepertsis et al. 2006). Among the statistical techniques, both principal component analysis (PCA) and cluster analysis (CA) are useful methods to discover common patterns in data distribution, leading to initial dimension reduction of datasets and helping its interpretation (Franco-Uría et al. 2009). PCA and CA assist to set up analyzed parameters in different factors/groups on the basis of contribution from their possible sources. FA and PCA have been widely used to expose variable redundancy and combine variables into single factors (Wilcke et al. 1998; Chen et al. 1999; Kumru and Bakac 2003; Navas and Machin 2002; Bretzel and Calderisi 2006). CA is often coupled to FA and PCA to provide groupings of individual variables according to distances or similarity indices (Facchinelli et al. 2001; Granero and Domingo 2002; Manta et al. 2002; Wang et al. 2005; Han et al. 2006). The explanation of the above data processing helps to identify pollution sources and allocate natural vs. anthropic contribution. The geographical information system (GIS) software is increasingly used in environmental studies because of its capability to expose non-point source contaminants (Sul$\tan$ 2007; Wang et al. 2006) and as a visual support in interpreting heavy metal spatial distribution.

In Bangladesh, determination of the heavy metals along the roadside is now a growing demand because of metal biomagnification in the food chain and their potential health impact. This study focuses on the identification of heavy metals in the roadside surface soils of Dhaka Aricha highway which will be served as a baseline study in Bangladesh for future monitoring of heavy metals and their levels around the roadside areas. Major objectives of the present study were (i) to measure the concentrations of metals ( $\mathrm{Fe}, \mathrm{Al}, \mathrm{Ca}, \mathrm{K}, \mathrm{Ti}, \mathrm{Mn}, \mathrm{Zr}, \mathrm{Sr}$, $\mathrm{Rb}, \mathrm{Zn}, \mathrm{Sn}, \mathrm{P}$, and $\mathrm{Ba}$ ) in surface soils of Dhaka Aricha highway; (ii) to determine potential pollution indices using enrichment factor (EF), geoaccumulation index $\left(I_{\text {geo }}\right)$, contamination factor $(\mathrm{CF})$, and pollution load 
index (PLI); and (iii) to define their natural/anthropogenic contributions using multivariate statistical methods. It is anticipated that the study would provide a baseline data regarding the distribution, accumulation, and sources of heavy metals in the roadside surface soils of Dhaka Aricha highway.

\section{Study area}

The area selected for the study was along the Dhaka Aricha road which lies between latitudes from $23^{\circ} 47^{\prime}$ $45.84^{\prime \prime} \mathrm{N}$ to $23^{\circ} 47^{\prime} 40.08^{\prime \prime} \mathrm{N}$ and longitude $90^{\circ} 16^{\prime}$ $36.04^{\prime \prime}$ E to $90^{\circ} 19^{\prime} 33.80^{\prime \prime}$ E which is $5.04 \mathrm{~km}$ long. The study area situated near Savar which is $17 \mathrm{~km}$ north from the Dhaka center runs northward. The study area was selected because it links with Dhaka City with comparatively high traffic density and has industrial influence. It carries, on an average, 9000 motor vehicles per day. The study area is surrounded by numerous brick fields and near the Amin Bazar landfill area. The Gabtoli Amin Bazar area is the transition point of Dhaka City, the largest bus stand acting as the entry and exit points of the city. Average elevation is $26.5 \mathrm{ft}$ above sea level. This area is perennially inundated by monsoon flood (June to August) and roadside runoff. The geology of this area is the uplifted Madhupur area which is covered by dark reddish-brown to brownish-red, mottled, sticky, and compact Madhupur Clay Residuum of the Pleistocene age, underlain by Plio-Pleistocene Dupi Tila sandstone formation (Maitra and Akhter 2011).

\section{Methods}

\section{Sample collection}

A total of 19 soil samples (prefixed S) was collected January, 2014, during dry seasons from roadside surface soils of Hemayetpur to Gabtoli area, Savar of Dhaka Aricha highway (Fig. 1). The soil samples were collected manually with a stainless steel spatula, cleaned after each sampling for foreign matter and carried within zip-mouthed PVC packages. All the soil samples were collected from the upper layer of the soil (about 0-5 cm). The soil samples were tightly packed and transferred to Institute of Food Science and Technology (IFST), Bangladesh Council of Scientific and Industrial Research (BCSIR), Dhaka, for metal determination in energy dispersive X-ray fluorescence (EDXRF). The samples were properly labeled and kept in room temperature.

\section{Sample preparation}

The collected soil samples were homogeneously mixed up. Unwanted portions like plant roots, stones, or other debris were removed. Then the samples were kept in a microwave oven about $48 \mathrm{~h}$ (at $60{ }^{\circ} \mathrm{C}$ ). The soil samples were kept in room temperature and grinded with mortar and pestle. Fifteen grams of the grinded samples was taken for pellet formation. In the VANEOX pressing machine, a 15-ton pressure was used to form the pellet. After the pellet formation, the samples were ready for the analysis in EDXRF.

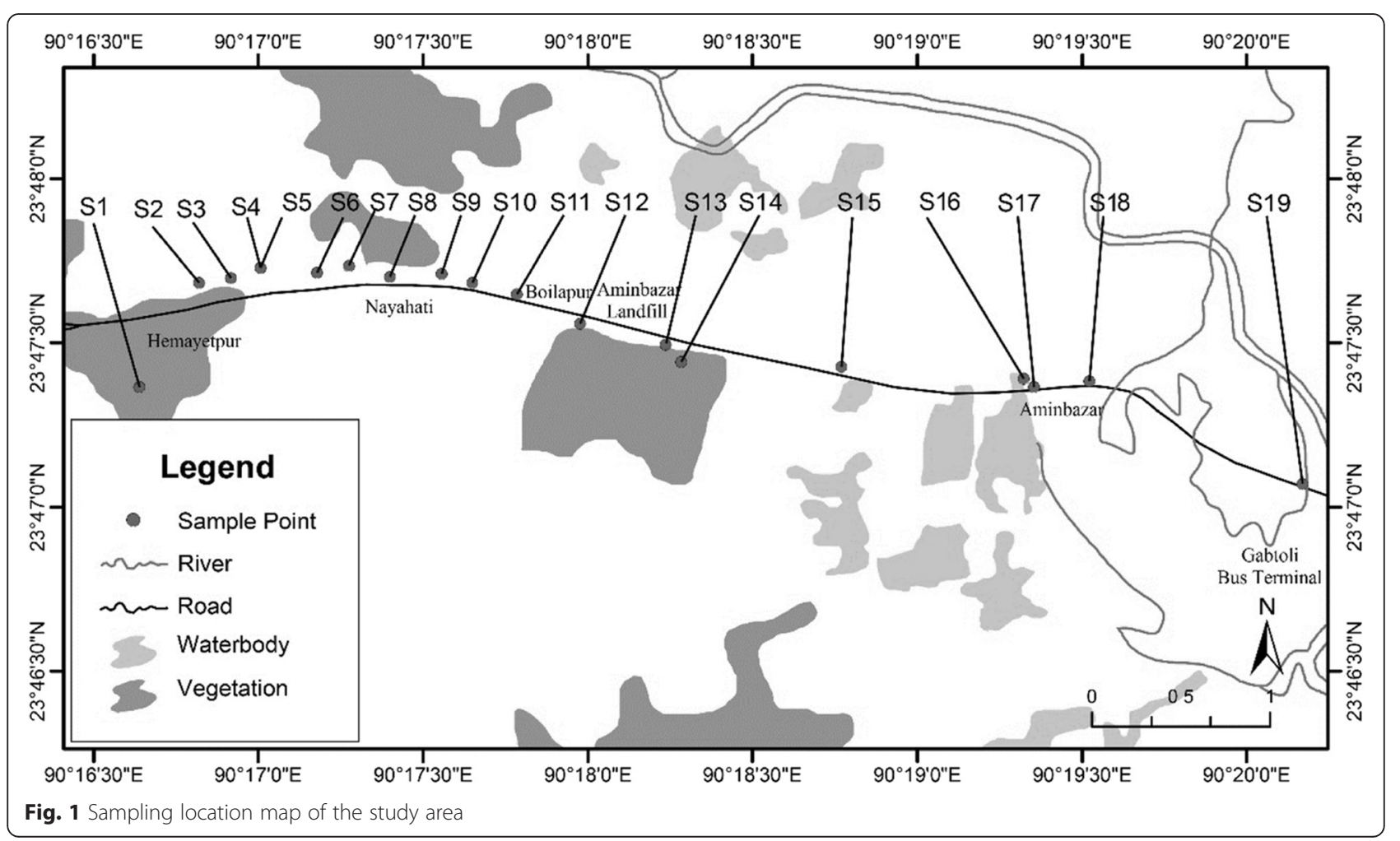




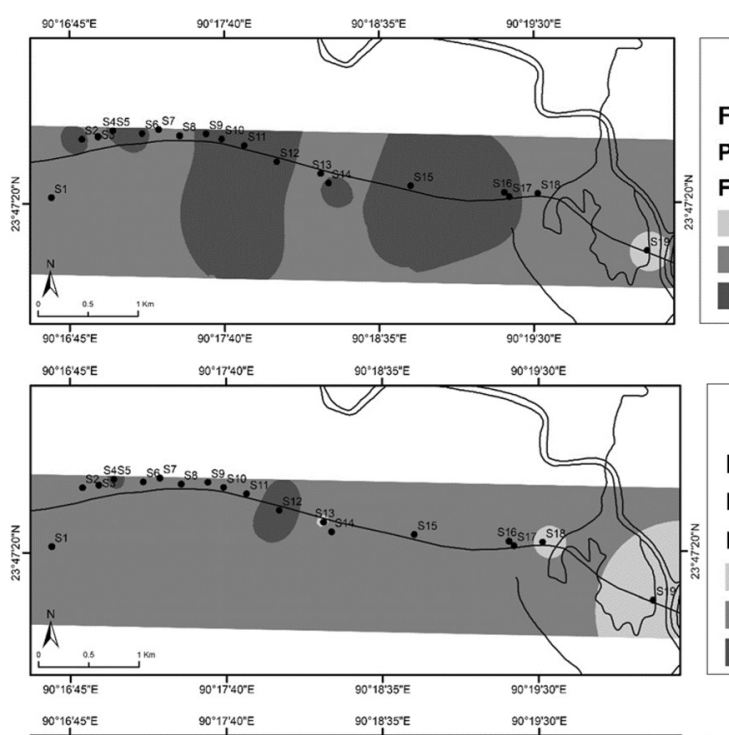

\section{Legend}

Fe Igeo

Prediction Map

Filled Contours

$-0.077437-0$

$0-1$

$1-1.407376$

Legend

Mn Igeo

Prediction Map

Filled Contours

$0.552541-1$

$1-2$

$2-2.908022$

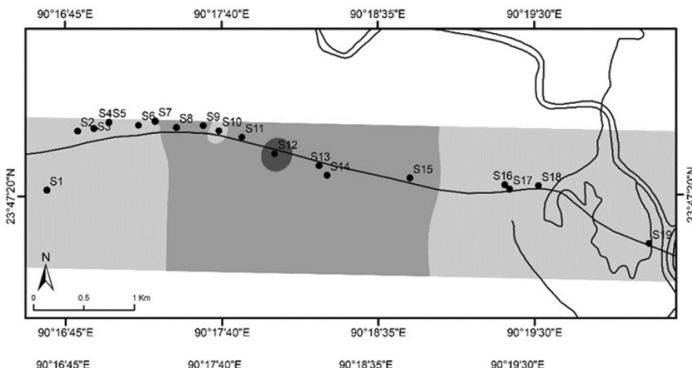

\section{Legend}

$P$ Igeo

Prediction Map

Filled Contours

$1.073657-2$

$2-3$

$3-3.440573$

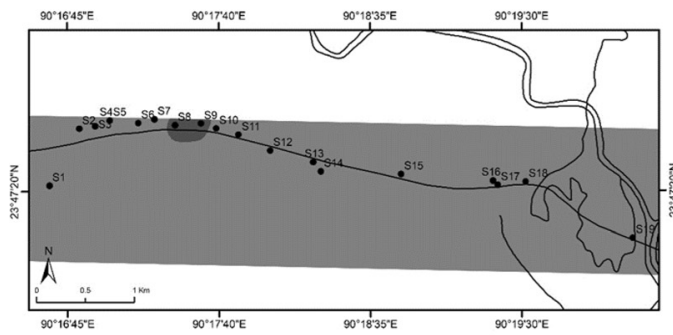

\section{Legend}

Sn Igeo

Prediction Map

Filled Contours

$3.473931-4$

$3.473931-4$
$4-4.187627$

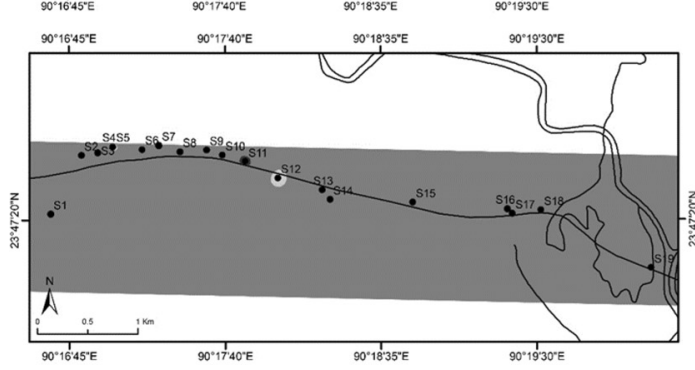

\section{Legend \\ Zn Igeo \\ Prediction Map \\ Filled Contours \\ $0.86755-1$ \\ $1-2$ \\ $2-2.121306$}

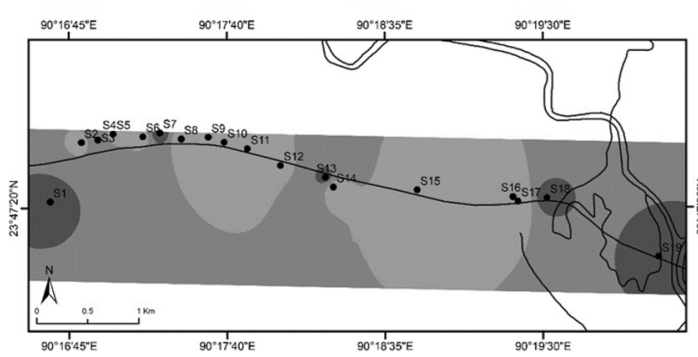

Legend

Zr Igeo

Prediction Map

Filled Contours

$1.984893-2$

$2-3$

3-4

$4-5.241586$

Fig. 2 Spatial distribution showing /geo value of metals in different sampling sites 


\section{Analysis of elements and data acquisition by EDXRF}

The elemental analysis was performed by ARL QUANT'X EDXRF, Thermo Scientific, USA, a spectrometer at IFST, BCSIR, Dhaka. EDXRF is equipped with a rhodium ( $R h)$ anode along with an assembly of eight filters (Al, cellulose, $\mathrm{Cu}$ thick, $\mathrm{Cu}$ thin, No, Pd medium, Pd thick, Pd thin), and a $\mathrm{Si}(\mathrm{Li})$ detector (with a $15-\mathrm{mm}^{2}$ area and less than an equal 76- $\mu \mathrm{m}$ beryllium window) was used for the determination of elements of the samples (Adyel et al. 2012). The sample is positioned in the Teflon cup assemblies. In the present work, the measurements were carried out in air. UniQUANT ED is the main system software to run the analysis in this EDXRF. The acquired data were processed with the help of a connected computer. The data is generated in percentage value. It can be converted to ppm value by multiplying by 10,000 (conversion process described in the software system). This instrument shows the $>5-\mathrm{ppm}$ value (instrument setup process). The value is generated by the average values of three time running value commands by the operator. The value is the average value of three-time running values in the instrument.

\section{Assessment of soil pollution}

EF

The enrichment factor can be calculated by dividing its ratio to the normalizing element by the same ratio found in the chosen baseline (Turekian and Wedepohl 1961). EF is calculated by the following equation:

$$
\mathrm{EF}=(\mathrm{Metal} / \mathrm{Fe})_{\text {Sample }} /(\mathrm{Metal} / \mathrm{Fe})_{\text {Background }}
$$

The EF values close to unity indicate crusted origin; those less than 1.0 suggest a possible mobilization or depletion of metals (Zsefer et al. 1996).

EFs $>1.0$ suggest possible anthropogenic origin. EFs $>10$ are suggest to be a non-crusted source. For geochemical normalization, iron (Fe) was used as the reference element (Daskalakis and O'Connor 1995).

Igeo

$I_{\text {geo }}$ is calculated to estimate the enrichment of metal concentrations above the background level which was proposed by Muller (1969). $I_{\text {geo }}$ is calculated using following equation:

$$
I_{\text {geo }}=\log _{2}\left(C_{\mathrm{n}} / 1.5 B_{\mathrm{n}}\right)
$$

where

$C_{\mathrm{n}}=$ concentration of the element in the enriched samples

$B_{\mathrm{n}}=$ background value of the element

The factor 1.5 is introduced to minimize the effect of possible variations in the background values which may be attributed to lithologic variations in the soils (Stoffers et al. 1986). Muller (1969) proposed the descriptive classes for increasing $I_{\text {geo }}$ value (Table 1 ).

CF

The CF is the ratio obtained by dividing the concentration of each metal in the soil by the baseline or background value (Turekian and Wedepohl 1961):

$$
\mathrm{CF}=C_{\text {heavy metal }} / C_{\text {background }}
$$

The contamination levels can be classified based on their intensities on a scale ranging from 1 to 6 . They were classified as $0=$ none, $1=$ none to medium, $2=$ moderate, 3 = moderately to strong, $4=$ strongly polluted, $5=$ strong to very strong, and 6 = very strong (Muller 1969).

PLI

For the entire sampling site, PLI has been determined as the $n$th root of the product of the $n$ CF (Usero et al. 2000):

$$
\mathrm{PLI}=\left(\mathrm{CF}_{1} \times \mathrm{CF}_{2} \times \mathrm{CF}_{3} \times \cdots \times \mathrm{CF}_{n}\right)^{1 / n}
$$

\section{Statistical analysis}

Analyzed data were subjected to multivariate analysis: PCA and FA and CA using SPSS version 22.0 and Microsoft Excel 2013.

\section{$P C A$ and $F A$}

PCA is designed to transform the original variables into new, uncorrelated variables (axes), called the principal components, which are linear combinations of the original variables. The new axes lie along the directions of maximum variance (Sarbu and Pop 2005). The principal component $(\mathrm{PC})$ can be expressed as the following:

$$
\begin{aligned}
z_{i j}= & a i_{1} x_{1} j+a i_{2} x_{2} j+a i_{3} x_{3} j+\cdots \ldots \ldots \ldots \ldots \ldots . . . \\
& +a_{i m} x_{m j}
\end{aligned}
$$

where $z$ is the component score, $a$ is the component loading, $x$ is the measured value of a variable, $i$ is the component number, $j$ is the sample number, and $m$ is the total number of variables.

Table 1 Muller's classification for the geoaccumulation index

\begin{tabular}{lll}
\hline geo value & Class & Soil quality \\
\hline$\leq 0$ & 0 & Unpolluted \\
$0-1$ & 1 & From unpolluted to moderately polluted \\
$1-2$ & 2 & Moderately polluted \\
$2-3$ & 3 & From moderately to strongly polluted \\
$3-4$ & 4 & Strongly polluted \\
$4-5$ & 5 & From strongly to extremely polluted \\
$>6$ & 6 & Extremely polluted \\
\hline
\end{tabular}


Table 2 Concentration, enrichment factor, geoaccumulation index, contamination factor, and pollution load index of metals for surface soil

\begin{tabular}{|c|c|c|c|c|c|c|c|c|c|c|c|c|c|c|c|c|c|c|c|c|}
\hline \multirow[t]{2}{*}{ Sampling site } & \multicolumn{5}{|l|}{$\mathrm{Fe}$} & \multicolumn{5}{|l|}{$\mathrm{Al}$} & \multicolumn{5}{|l|}{$\mathrm{Ca}$} & \multicolumn{5}{|l|}{ K } \\
\hline & $\begin{array}{l}\text { Conc. } \\
\text { (ppm) }\end{array}$ & EF & $I_{\text {geo }}$ & CF & PLI & $\begin{array}{l}\text { Conc. } \\
\text { (ppm) }\end{array}$ & EF & Igeo & CF & PLI & $\begin{array}{l}\text { Conc. } \\
\text { (ppm) }\end{array}$ & $E F$ & Igeo & CF & PLI & $\begin{array}{l}\text { Conc. } \\
\text { (ppm) }\end{array}$ & EF & Igeo & CF & PLI \\
\hline S1 & 115,000 & 1 & 0.700 & 2.436 & 2.877 & 25,500 & 0.131 & -2.234 & 0.319 & 0.597 & 52,200 & 0.969 & 0.655 & 2.362 & 1.247 & 49,900 & 0.770 & 0.323 & 1.876 & 2.033 \\
\hline S2 & 156,200 & 1 & 1.142 & 3.309 & & 80,100 & 0.303 & -0.583 & 1.001 & & 11,000 & 0.150 & -1.592 & 0.498 & & 46,100 & 0.524 & 0.208 & 1.733 & \\
\hline S3 & 106,200 & 1 & 0.585 & 2.250 & & 31,600 & 0.176 & -1.925 & 0.395 & & 77,000 & 1.549 & 1.216 & 3.484 & & 54,600 & 0.912 & 0.453 & 2.053 & \\
\hline S4 & 151,800 & 1 & 1.100 & 3.216 & & 80,200 & 0.312 & -0.581 & 1.003 & & 11,300 & 0.159 & -1.553 & 0.511 & & 39,800 & 0.465 & -0.004 & 1.496 & \\
\hline S5 & 171,200 & 1 & 1.274 & 3.627 & & 84,600 & 0.292 & -0.504 & 1.058 & & 10,800 & 0.135 & -1.618 & 0.489 & & 50,000 & 0.518 & 0.326 & 1.880 & \\
\hline S6 & 163,400 & 1 & 1.207 & 3.462 & & 76,100 & 0.275 & -0.657 & 0.951 & & 19,800 & 0.259 & -0.744 & 0.896 & & 57,600 & 0.626 & 0.530 & 2.165 & \\
\hline S7 & 103,200 & 1 & 0.544 & 2.186 & & 20,300 & 0.116 & -2.563 & 0.254 & & 38,700 & 0.801 & 0.223 & 1.751 & & 48,500 & 0.834 & 0.282 & 1.823 & \\
\hline S8 & 108,400 & 1 & 0.615 & 2.297 & & 38,400 & 0.209 & -1.644 & 0.480 & & 36,100 & 0.711 & 0.123 & 1.633 & & 63,100 & 1.033 & 0.661 & 2.372 & \\
\hline S9 & 166,600 & 1 & 1.235 & 3.530 & & 72,900 & 0.258 & -0.719 & 0.911 & & 17,200 & 0.220 & -0.947 & 0.778 & & 57,900 & 0.617 & 0.537 & 2.177 & \\
\hline S10 & 182,400 & 1 & 1.365 & 3.864 & & 55,400 & 0.179 & -1.115 & 0.693 & & 30,000 & 0.351 & -0.144 & 1.357 & & 63,000 & 0.613 & 0.659 & 2.368 & \\
\hline S11 & 187,800 & 1 & 1.407 & 3.979 & & 78,600 & 0.247 & -0.610 & 0.983 & & 21,100 & 0.240 & -0.652 & 0.955 & & 58,600 & 0.554 & 0.555 & 2.203 & \\
\hline S12 & 169,000 & 1 & 1.255 & 3.581 & & 45,700 & 0.160 & -1.393 & 0.571 & & 61,100 & 0.772 & 0.882 & 2.765 & & 45,500 & 0.478 & 0.189 & 1.711 & \\
\hline S13 & 78,900 & 1 & 0.156 & 1.672 & & 20,700 & 0.155 & -2.535 & 0.259 & & 38,200 & 1.034 & 0.205 & 1.729 & & 56,800 & 1.277 & 0.510 & 2.135 & \\
\hline S14 & 177,600 & 1 & 1.327 & 3.763 & & 76,000 & 0.252 & -0.659 & 0.950 & & 31,800 & 0.382 & -0.060 & 1.439 & & 62,900 & 0.628 & 0.657 & 2.365 & \\
\hline S15 & 156,400 & 1 & 1.143 & 3.314 & & 62,600 & 0.236 & -0.939 & 0.783 & & 27,700 & 0.378 & -0.259 & 1.253 & & 55,500 & 0.630 & 0.476 & 2.086 & \\
\hline S16 & 161,000 & 1 & 1.185 & 3.411 & & 87,100 & 0.319 & -0.462 & 1.089 & & 22,800 & 0.302 & -0.540 & 1.032 & & 60,700 & 0.669 & 0.605 & 2.282 & \\
\hline S17 & 170,300 & 1 & 1.266 & 3.608 & & 72,700 & 0.252 & -0.723 & 0.909 & & 23,200 & 0.291 & -0.515 & 1.050 & & 60,700 & 0.632 & 0.605 & 2.282 & \\
\hline S18 & 94,900 & 1 & 0.423 & 2.011 & & 20,400 & 0.127 & -2.556 & 0.255 & & 38,300 & 0.862 & 0.208 & 1.733 & & 46,900 & 0.877 & 0.233 & 1.763 & \\
\hline S19 & 67,100 & 1 & -0.077 & 1.422 & & 17,000 & 0.149 & -2.819 & 0.213 & & 34,300 & 1.092 & 0.049 & 1.552 & & 58,100 & 1.536 & 0.542 & 2.184 & \\
\hline \multirow[t]{2}{*}{ Sampling site } & \multicolumn{5}{|l|}{$\mathrm{Ti}$} & \multicolumn{5}{|l|}{$\mathrm{Mn}$} & \multicolumn{5}{|l|}{$\mathrm{Zr}$} & \multicolumn{5}{|l|}{$\mathrm{Sr}$} \\
\hline & $\begin{array}{l}\text { Conc. } \\
\text { (ppm) }\end{array}$ & $\mathrm{EF}$ & $I_{\text {geo }}$ & CF & PLI & $\begin{array}{l}\text { Conc. } \\
\text { (ppm) }\end{array}$ & EF & Igeo & CF & PLI & $\begin{array}{l}\text { Conc. } \\
\text { (ppm) }\end{array}$ & EF & Igeo & CF & PLI & $\begin{array}{l}\text { Conc. } \\
\text { (ppm) }\end{array}$ & EF & $I_{\text {geo }}$ & CF & PLI \\
\hline S1 & 9200 & 0.821 & 0.415 & 2.000 & 2.395 & 3020 & 1.458 & 1.244 & 3.553 & 4.351 & 7300 & 18.726 & 4.927 & 45.625 & 13.515 & 813 & 1.112 & 0.853 & 2.710 & 2.157 \\
\hline S2 & 12,100 & 0.795 & 0.810 & 2.630 & & 3960 & 1.408 & 1.635 & 4.659 & & 1520 & 2.871 & 2.663 & 9.500 & & 371 & 0.374 & -0.279 & 1.237 & \\
\hline S3 & 9100 & 0.879 & 0.399 & 1.978 & & 2680 & 1.401 & 1.072 & 3.153 & & 3430 & 9.528 & 3.837 & 21.438 & & 942 & 1.396 & 1.066 & 3.140 & \\
\hline S4 & 12,400 & 0.838 & 0.846 & 2.696 & & 12,400 & 4.536 & 3.282 & 14.588 & & 1400 & 2.721 & 2.544 & 8.750 & & 294 & 0.305 & -0.614 & 0.980 & \\
\hline S5 & 13,200 & 0.791 & 0.936 & 2.870 & & 3910 & 1.268 & 1.617 & 4.600 & & 1650 & 2.843 & 2.781 & 10.313 & & 334 & 0.307 & -0.430 & 1.113 & \\
\hline S6 & 12,100 & 0.760 & 0.810 & 2.630 & & 3450 & 1.172 & 1.436 & 4.059 & & 1340 & 2.419 & 2.481 & 8.375 & & 558 & 0.537 & 0.310 & 1.860 & \\
\hline S7 & 11,500 & 1.143 & 0.737 & 2.500 & & 2540 & 1.367 & 0.994 & 2.988 & & 9080 & 25.955 & 5.242 & 56.750 & & 702 & 1.070 & 0.642 & 2.340 & \\
\hline S8 & 9200 & 0.871 & 0.415 & 2.000 & & 3020 & 1.547 & 1.244 & 3.553 & & 950 & 2.585 & 1.985 & 5.938 & & 902 & 1.309 & 1.003 & 3.007 & \\
\hline
\end{tabular}


Table 2 Concentration, enrichment factor, geoaccumulation index, contamination factor, and pollution load index of metals for surface soil (Continued)

\begin{tabular}{|c|c|c|c|c|c|c|c|c|c|c|c|c|c|c|c|c|c|c|c|c|}
\hline S9 & 11,700 & 0.721 & 0.762 & 2.543 & & 3860 & 1.287 & 1.598 & 4.541 & & 1700 & 3.010 & 2.824 & 10.625 & & 515 & 0.486 & 0.195 & 1.717 & \\
\hline S10 & 17,800 & 1.001 & 1.367 & 3.870 & & 4860 & 1.480 & 1.930 & 5.718 & & 1320 & 2.135 & 2.459 & 8.250 & & 773 & 0.667 & 0.781 & 2.577 & \\
\hline S11 & 12,000 & 0.656 & 0.798 & 2.609 & & 4030 & 1.192 & 1.660 & 4.741 & & 1480 & 2.325 & 2.624 & 9.250 & & 552 & 0.462 & 0.295 & 1.840 & \\
\hline S12 & 15,300 & 0.929 & 1.149 & 3.326 & & 9570 & 3.144 & 2.908 & 11.259 & & 1700 & 2.967 & 2.824 & 10.625 & & 1050 & 0.978 & 1.222 & 3.500 & \\
\hline S13 & 7800 & 1.014 & 0.177 & 1.696 & & 2240 & 1.577 & 0.813 & 2.635 & & 5710 & 21.349 & 4.572 & 35.688 & & 905 & 1.805 & 1.008 & 3.017 & \\
\hline S14 & 13,000 & 0.751 & 0.914 & 2.826 & & 4070 & 1.273 & 1.675 & 4.788 & & 1180 & 1.960 & 2.298 & 7.375 & & 779 & 0.690 & 0.792 & 2.597 & \\
\hline S15 & 12,200 & 0.800 & 0.822 & 2.652 & & 3460 & 1.228 & 1.440 & 4.071 & & 1390 & 2.622 & 2.534 & 8.688 & & 644 & 0.648 & 0.517 & 2.147 & \\
\hline S16 & 12,100 & 0.771 & 0.810 & 2.630 & & 4200 & 1.449 & 1.720 & 4.941 & & 1000 & 1.832 & 2.059 & 6.250 & & 686 & 0.670 & 0.608 & 2.287 & \\
\hline S17 & 11,700 & 0.705 & 0.762 & 2.543 & & 3960 & 1.291 & 1.635 & 4.659 & & 1100 & 1.905 & 2.196 & 6.875 & & 637 & 0.588 & 0.501 & 2.123 & \\
\hline S18 & 7500 & 0.811 & 0.120 & 1.630 & & 2130 & 1.246 & 0.740 & 2.506 & & 7190 & 22.350 & 4.905 & 44.938 & & 731 & 1.212 & 0.700 & 2.437 & \\
\hline S19 & 5920 & 0.905 & -0.221 & 1.287 & & 1870 & 1.548 & 0.553 & 2.200 & & 5440 & 23.917 & 4.503 & 34.000 & & 776 & 1.820 & 0.786 & 2.587 & \\
\hline \multirow[t]{2}{*}{ Sampling site } & $\mathrm{Rb}$ & & & & & $\mathrm{Zn}$ & & & & & Sn & & & & & P & & & & \\
\hline & $\begin{array}{l}\text { Conc. } \\
\text { (ppm) }\end{array}$ & $\mathrm{EF}$ & Igeo & $\mathrm{CF}$ & PLI & $\begin{array}{l}\text { Conc. } \\
\text { (ppm) }\end{array}$ & EF & Igeo & $\mathrm{CF}$ & PLI & $\begin{array}{l}\text { Conc. } \\
\text { (ppm) }\end{array}$ & $\mathrm{EF}$ & Igeo & CF & PLI & $\begin{array}{l}\text { Conc. } \\
\text { (ppm) }\end{array}$ & $\mathrm{EF}$ & Igeo & $\mathrm{CF}$ & PLI \\
\hline S1 & 430 & 1.261 & 1.034 & 3.071 & 3.561 & 350 & 1.512 & 1.296 & 3.684 & 3.993 & 123 & 8.414 & 3.773 & 20.500 & 20.866 & 2210 & 1.296 & 1.074 & 3.157 & 5.71 \\
\hline S2 & 430 & 0.928 & 1.034 & 3.071 & & 320 & 1.018 & 1.167 & 3.368 & & 126 & 6.346 & 3.807 & 21.000 & & 2310 & 0.997 & 1.138 & 3.300 & \\
\hline S3 & 473 & 1.502 & 1.171 & 3.379 & & 363 & 1.698 & 1.349 & 3.821 & & 124 & 9.185 & 3.784 & 20.667 & & 4560 & 2.895 & 2.119 & 6.514 & \\
\hline S4 & 427 & 0.948 & 1.024 & 3.050 & & 287 & 0.939 & 1.010 & 3.021 & & 123 & 6.374 & 3.773 & 20.500 & & 3010 & 1.337 & 1.519 & 4.300 & \\
\hline S5 & 520 & 1.024 & 1.308 & 3.714 & & 264 & 0.766 & 0.890 & 2.779 & & 102 & 4.687 & 3.503 & 17.000 & & 2590 & 1.020 & 1.303 & 3.700 & \\
\hline S6 & 580 & 1.197 & 1.466 & 4.143 & & 370 & 1.125 & 1.377 & 3.895 & & 128 & 6.162 & 3.830 & 21.333 & & 3850 & 1.589 & 1.874 & 5.500 & \\
\hline S7 & 391 & 1.277 & 0.897 & 2.793 & & 423 & 2.036 & 1.570 & 4.453 & & 105 & 8.004 & 3.544 & 17.500 & & 4205 & 2.747 & 2.002 & 6.007 & \\
\hline S8 & 542 & 1.686 & 1.368 & 3.871 & & 431.5 & 1.978 & 1.598 & 4.542 & & 164 & 11.902 & 4.188 & 27.333 & & 4560 & 2.836 & 2.119 & 6.514 & \\
\hline S9 & 500 & 1.012 & 1.252 & 3.571 & & 440 & 1.312 & 1.627 & 4.632 & & 158 & 7.461 & 4.134 & 26.333 & & 4410 & 1.785 & 2.070 & 6.300 & \\
\hline S10 & 620 & 1.146 & 1.562 & 4.429 & & 330 & 0.899 & 1.212 & 3.474 & & 136 & 5.865 & 3.918 & 22.667 & & 3630 & 1.342 & 1.790 & 5.186 & \\
\hline S11 & 640 & 1.149 & 1.608 & 4.571 & & 620 & 1.640 & 2.121 & 6.526 & & 132 & 5.529 & 3.874 & 22.000 & & 6070 & 2.179 & 2.531 & 8.671 & \\
\hline S12 & 660 & 1.317 & 1.652 & 4.714 & & 260 & 0.764 & 0.868 & 2.737 & & 100 & 4.655 & 3.474 & 16.667 & & 11400 & 4.548 & 3.441 & 16.286 & \\
\hline$\$ 13$ & 372 & 1.590 & 0.825 & 2.657 & & 415 & 2.613 & 1.542 & 4.368 & & 112 & 11.167 & 3.637 & 18.667 & & 8065 & 6.892 & 2.941 & 11.521 & \\
\hline S14 & 650 & 1.234 & 1.630 & 4.643 & & 570 & 1.595 & 2.000 & 6.000 & & 143 & 6.334 & 3.990 & 23.833 & & 4730 & 1.796 & 2.171 & 6.757 & \\
\hline S15 & 538 & 1.160 & 1.357 & 3.843 & & 310 & 0.985 & 1.121 & 3.263 & & 120 & 6.036 & 3.737 & 20.000 & & 4680 & 2.018 & 2.156 & 6.686 & \\
\hline S16 & 680 & 1.424 & 1.695 & 4.857 & & 290 & 0.895 & 1.025 & 3.053 & & 118 & 5.766 & 3.713 & 19.667 & & 2400 & 1.005 & 1.193 & 3.429 & \\
\hline S17 & 600 & 1.188 & 1.515 & 4.286 & & 420 & 1.225 & 1.559 & 4.421 & & 148 & 6.837 & 4.040 & 24.667 & & 2960 & 1.172 & 1.495 & 4.229 & \\
\hline S18 & 335 & 1.190 & 0.674 & 2.393 & & 470 & 2.461 & 1.722 & 4.947 & & 132 & 10.942 & 3.874 & 22.000 & & 4000 & 2.842 & 1.930 & 5.714 & \\
\hline S19 & 325 & 1.633 & 0.630 & 2.321 & & 490 & 3.628 & 1.782 & 5.158 & & 107 & 12.544 & 3.572 & 17.833 & & 3600 & 3.618 & 1.778 & 5.143 & \\
\hline
\end{tabular}


Table 3 Concentration, enrichment factor, geoaccumulation index, contamination factor, and pollution load index of metals for surface soil

\begin{tabular}{llllll}
\hline Sampling site & Ba & & & & \\
\cline { 2 - 6 } & Concentration (ppm) & EF & \multicolumn{1}{l}{ Igeo } & CF & PLI \\
\hline S1 & 1520 & 1.076 & 0.805 & 2.621 & 2.589 \\
S2 & 1670 & 0.870 & 0.941 & 2.879 & \\
S3 & 430 & 0.330 & -1.017 & 0.741 & \\
S4 & 1500 & 0.804 & 0.786 & 2.586 & \\
S5 & 1350 & 0.642 & 0.634 & 2.328 & \\
S6 & 1780 & 0.887 & 1.033 & 3.069 & \\
S7 & 1440 & 1.136 & 0.727 & 2.483 & \\
S8 & 1680 & 1.261 & 0.949 & 2.897 & \\
S9 & 1610 & 0.786 & 0.888 & 2.776 & \\
S10 & 1680 & 0.750 & 0.949 & 2.897 & \\
S11 & 1680 & 0.728 & 0.949 & 2.897 & \\
S12 & 1880 & 0.905 & 1.112 & 3.241 & \\
S13 & 1370 & 1.413 & 0.655 & 2.362 & \\
S14 & 1930 & 0.884 & 1.150 & 3.328 & \\
S15 & 1600 & 0.833 & 0.879 & 2.759 & \\
S16 & 1650 & 0.834 & 0.923 & 2.845 & \\
S17 & 1910 & 0.913 & 1.134 & 3.293 & \\
S18 & 1550 & 1.329 & 0.833 & 2.672 & \\
S19 & 1350 & 1.637 & 0.634 & 2.328 & \\
\hline
\end{tabular}

PCA of the normalized variables was performed to extract significant PCs and to further reduce the contribution of variables with minor significance; these PCs were subjected to varimax rotation with Kaiser Normalization generating VFs (Brumelis et al. 2000; Singh et al. 2004, 2005a, b; Love et al. 2004; Abdul-Wahab et al. 2005). The factor analysis can be shown by the following equation:

$$
\begin{aligned}
z_{j i}= & a_{f_{1}} f_{1 i}+a_{f_{2} f 2 i}+a_{f_{3}} f_{3 i}+\cdots \ldots \ldots \ldots \ldots \ldots \\
& +a_{f_{m}} f_{m i}+e_{f i}
\end{aligned}
$$

where

$z=$ measured variable

$a=$ factor loading

$f=$ factor score

$e=$ residual term accounting for errors or other sources of variation

$i=$ sample number

$m=$ total number of factors

\section{$C A$}

The purpose of CA is to identify groups or clusters of similar sites on the basis of similarities within a class and dissimilarities between different classes (Sparks 2000). CA is a group of multivariate techniques whose primary purpose is to assemble objects based on the characteristics they possess. CA classifies objects so that each object is similar to the others. The resulting clusters of objects should then exhibit high internal (within cluster) homogeneity and high external (between clusters) heterogeneity.

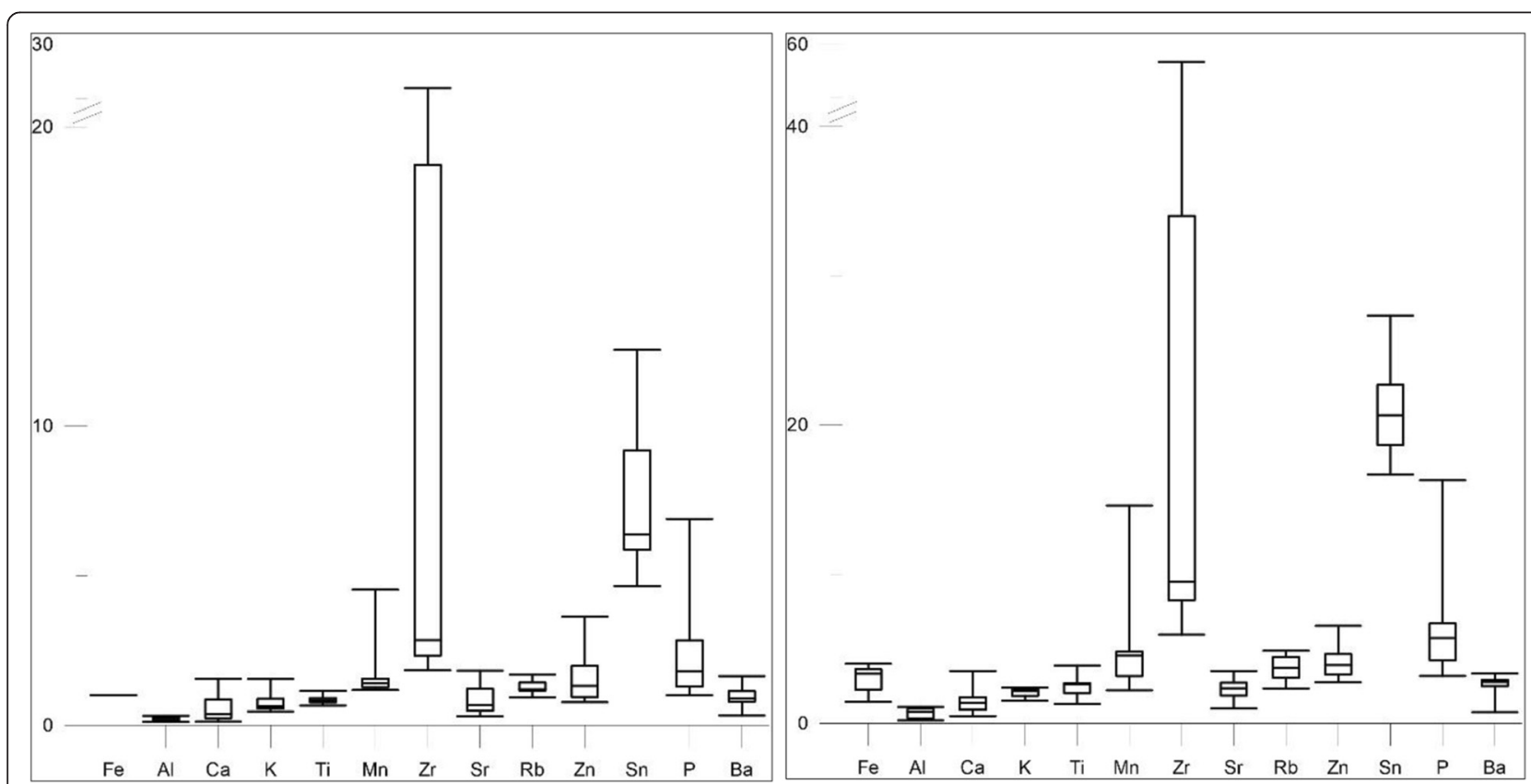

Fig. 3 Box-whisker plots of the EF (left) and CF (right) of metals in soils (the whisker shows the minimum and maximum values and the line of each plot is the median value) 
In this study, hierarchical agglomerative CA was performed on the normalized dataset by means of the Ward's method, using squared Euclidean distances as a measure of similarity. CA was applied on experimental data standardized through z-scale transformation in order to avoid misclassification due to wide differences in data dimensionality (Liu et al. 2003).

\section{Inverse distance weighting}

The factor scores from the R-mode PCA and $I_{\text {geo }}$ values were used with ArcGIS 10.1 to determine the spatial variations of the dominant processes and soil pollution level using the inverse distance weighting (IDW) method. The IDW method estimates the values of an attribute at unsampled points using a linear combination of values at sampled points weighted by an inverse function of the distance from the point of interest to the sampled points. The weights can be expressed as follows:

$$
\lambda_{\mathrm{i}}=\frac{1 / d_{i}^{\mathrm{P}}}{\sum_{i=1}^{n} 1 / d_{i}{ }^{\mathrm{P}}}
$$

where

$d_{i}=$ the distance between $x_{0}$ and $x_{i}$

$p=$ power parameter

$n=$ the number of sampled points used for the estimation

The main factor affecting the accuracy of IDW is the value of the power parameter (Isaaks and Srivastava 1989). The most popular choice of $p$ is 2 , and the resulting method is often called inverse square distance.

\section{Results and discussion}

Pollution indices

The EF values for Fe is 1 in all sampling sites; $\mathrm{Al}$ ranges from 0.116 to 0.319 ; $\mathrm{Ca}$ from 0.135 to 1.549 ; $\mathrm{K}$ from 0.465 to 1.536; Ti from 0.656 to 1.143 ; $\mathrm{Mn}$ from 1.172 to 4.536; $\mathrm{Zr}$ from 1.832 to 25.955; Sr from 0.305 to 1.820 ; $\mathrm{Rb}$ from 0.928 to 1.686 ; $\mathrm{Zn}$ from 0.764 to 3.628 ; $\mathrm{Sn}$ from 4.655 to 12.544; P from 0.997 to 6.892; and $\mathrm{Ba}$ from 0.330 to 1.637 (Tables 2 and 3). The average order of the $\mathrm{EF}$ values for the metals is $\mathrm{Zr}(8.106)>\mathrm{Sn}(7.590)>\mathrm{P}$ $(2.311)>\mathrm{Mn}(1.625)>\mathrm{Zn}(1.531)>\mathrm{Rb}(1.256)>\mathrm{Fe}(1)>\mathrm{Ba}$ $(0.948)>\mathrm{Sr}(0.865)>\mathrm{Ti}(0.840)>\mathrm{K}(0.747)>\mathrm{Ca}(0.561)>$ $\mathrm{Al}$ (0.218). The EF values between 0.05 and 1.5 indicate that the metal is entirely from crustal materials or natural processes; on the other hand, the EF values higher than 1.5 indicate that the sources are likely to be anthropogenic (Zhang and Liu 2002). According to Han et al. (2006), EF $\leq 2$ suggests deficiency to minimal metal enrichment, whereas EF $>2$ suggests higher degrees of metal enrichment.

The $I_{\text {geo }}$ brought in by Muller (1969) is used as a reference of calculating the level of metal pollution.
Table 4 Matrix of three principal components

\begin{tabular}{|c|c|c|c|}
\hline \multirow[b]{2}{*}{ Elements } & \multicolumn{3}{|c|}{ Component } \\
\hline & PC1 & PC2 & PC3 \\
\hline $\mathrm{Fe}$ & 0.927 & -0.221 & -0.059 \\
\hline $\mathrm{Al}$ & 0.789 & -0.541 & -0.053 \\
\hline $\mathrm{Ca}$ & -0.355 & 0.846 & -0.044 \\
\hline K & 0.277 & 0.148 & 0.853 \\
\hline $\mathrm{Ti}$ & 0.840 & 0.015 & -0.287 \\
\hline $\mathrm{Mn}$ & 0.507 & 0.004 & -0.663 \\
\hline $\mathrm{Zr}$ & -0.854 & 0.175 & -0.085 \\
\hline $\mathrm{Sr}$ & -0.189 & 0.927 & 0.237 \\
\hline $\mathrm{Rb}$ & 0.911 & 0.211 & 0.174 \\
\hline Zn & -0.161 & 0.031 & 0.745 \\
\hline Sn & 0.280 & -0.185 & 0.701 \\
\hline$P$ & 0.174 & 0.789 & -0.162 \\
\hline $\mathrm{Ba}$ & 0.600 & -0.122 & 0.172 \\
\hline Eigenvalue (total) & 5.149 & 2.473 & 2.253 \\
\hline$\%$ of total variance & 39.610 & 19.020 & 17.331 \\
\hline Cumulative $\%$ of variance & 39.610 & 58.630 & 75.961 \\
\hline
\end{tabular}

Moderate to strong loadings are in boldface

Table 5 Component matrix showing three factor models for sampling sites

\begin{tabular}{|c|c|c|c|}
\hline Elements & PC1 & PC2 & PC3 \\
\hline S1 & -1.112 & 0.205 & -0.218 \\
\hline S2 & 0.009 & -1.544 & -0.685 \\
\hline S3 & -1.046 & 1.295 & -0.125 \\
\hline S4 & 0.265 & -1.428 & -2.137 \\
\hline S5 & 0.228 & -1.310 & -1.138 \\
\hline S6 & 0.583 & -0.505 & 0.256 \\
\hline S7 & -1.301 & 0.151 & -0.555 \\
\hline S8 & 0.031 & 0.496 & 1.546 \\
\hline S9 & 0.410 & -0.745 & 0.816 \\
\hline S10 & 1.192 & 0.417 & 0.230 \\
\hline S11 & 0.860 & -0.114 & 0.992 \\
\hline S12 & 1.364 & 2.730 & -1.984 \\
\hline S13 & -1.183 & 1.002 & 0.117 \\
\hline S14 & 1.071 & 0.337 & 1.380 \\
\hline S15 & 0.349 & -0.050 & -0.237 \\
\hline S16 & 0.816 & -0.283 & 0.060 \\
\hline S17 & 0.750 & -0.442 & 0.952 \\
\hline S18 & -1.536 & -0.157 & 0.194 \\
\hline S19 & -1.751 & -0.054 & 0.535 \\
\hline
\end{tabular}

Moderate to strong factor loadings are boldface 


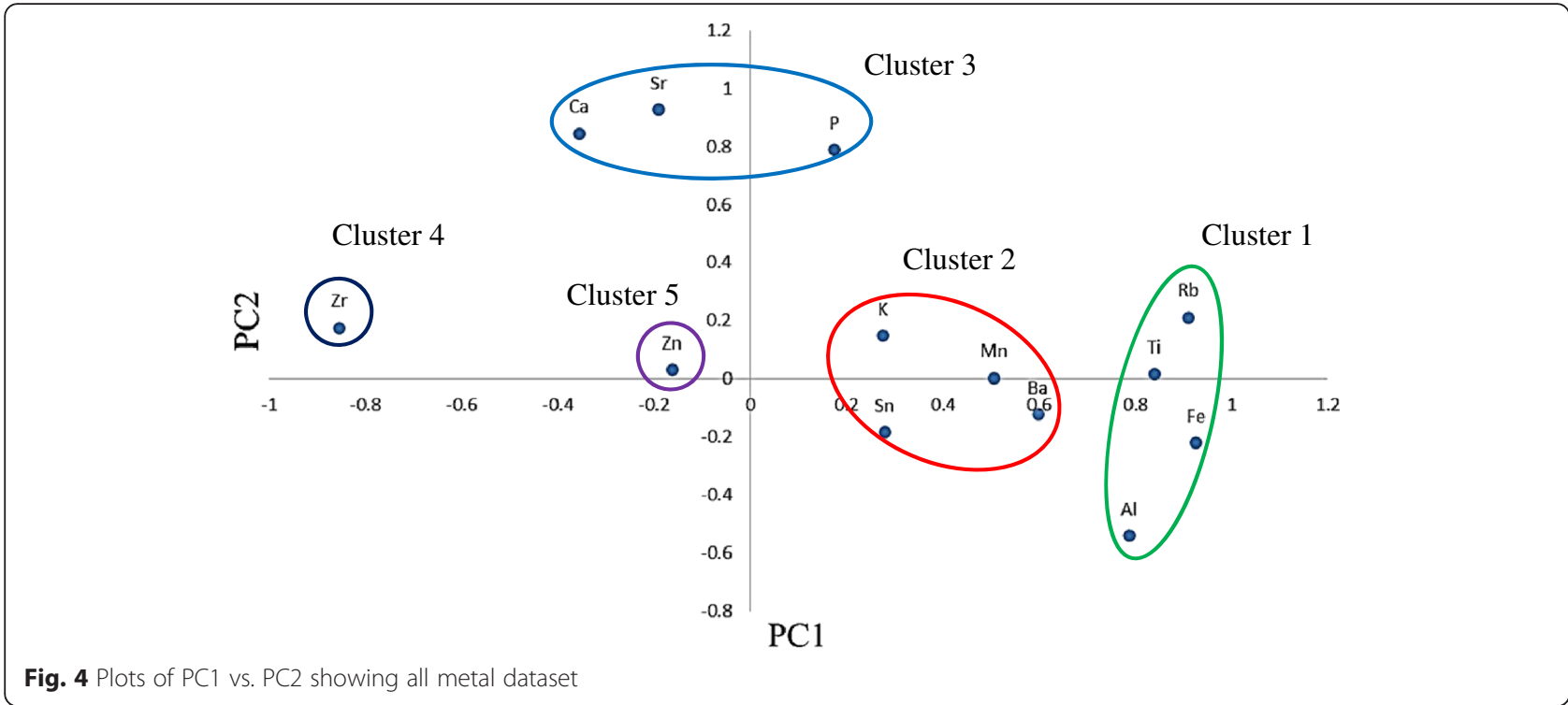

From Tables 2 and 3, the $I_{\text {geo }}$ value of Fe is $0.939 \pm 0.444$; $\mathrm{K}$ is $0.439 \pm 0.190$; $\mathrm{Ti}$ is $0.675 \pm 0.375$; $\mathrm{Mn}$ is $1.537 \pm 0.667$; $\mathrm{Zr}$ is $3.172 \pm 1.096$; $\mathrm{Sr}$ is $0.524 \pm 0.509$; $\mathrm{Rb}$ is $1.247 \pm 0.337$; $\mathrm{Zn}$ is 1.412 \pm 0.358 ; $\mathrm{Sn}$ is $3.798 \pm 0.201$; $\mathrm{P}$ is $1.929 \pm 0.604$; and $\mathrm{Ba}$ is $0.788 \pm 0.464$. According to Table 1 , overall sampling site is unpolluted by $\mathrm{Al}$ and $\mathrm{Ca}$; unpolluted to moderately polluted by $\mathrm{Fe}, \mathrm{K}, \mathrm{Ti}, \mathrm{Sr}$, and $\mathrm{Ba}$; moderately polluted by $\mathrm{Mn}, \mathrm{Rb}, \mathrm{Zn}$, and $\mathrm{P}$; and strongly polluted by $\mathrm{Sn}$ and $\mathrm{Zr}$. The distributions of $I_{\text {geo }}$ in different sites are shown in Fig. 2. The CFs of the metals range from 1.422 to $3.979(\mathrm{Fe}) ; 0.213$ to $1.089(\mathrm{Al}) ; 0.489$ to $3.484(\mathrm{Ca})$; 1.496 to $2.372(\mathrm{~K}) ; 1.287$ to $3.870(\mathrm{Ti}) ; 2.200$ to 14.588 $(\mathrm{Mn}) ; 5.938$ to $56.750(\mathrm{Zr}) ; 0.980$ to $3.500(\mathrm{Sr}) ; 2.321$ to $4.857(\mathrm{Rb}) ; 2.737$ to $6.526(\mathrm{Zn}) ; 16.667$ to 27.333 (Sn); 3.157 to $16.286(\mathrm{P})$; and 0.741 to 3.328 (Ba) (Tables 2 and 3). PLI calculated from CF depicts that the soils are strongly contaminated by $\mathrm{Zr}$ and $\mathrm{Sn}$ (Tables 2 and 3). Figure 3 shows the Box-whisker plots of Enrichment Factor (EF) and Contamination Factor (CF) of metals in soil of the area. CF, EF, and $I_{\text {geo }}$ show minor similarity with Jayaprakash et al.'s (2009) study in the Indian coast area.

\section{PCA and FA}

Using varimax rotation with Kaiser Normalization, PCA was performed on the metal data maximizing the sum of the variance of the factor coefficients. This technique clusters variables into different groups. The PCA results obtained for the elements are shown in Table 4. Three principal components having eigenvalues greater than 1

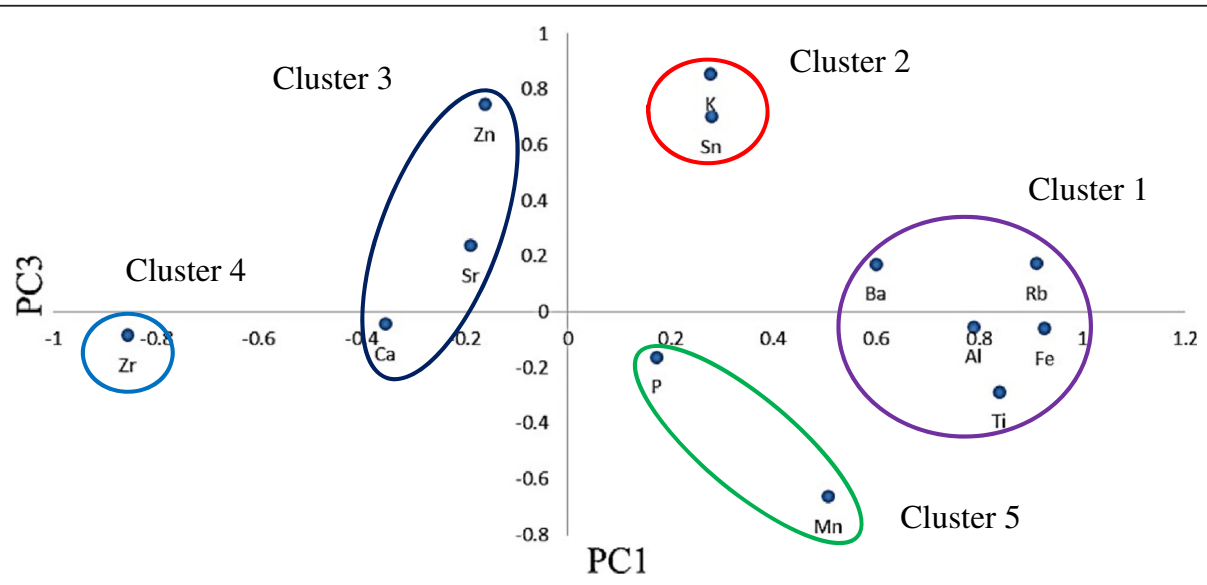

Fig. 5 Plots of PC1 vs. PC3 showing all metal dataset 

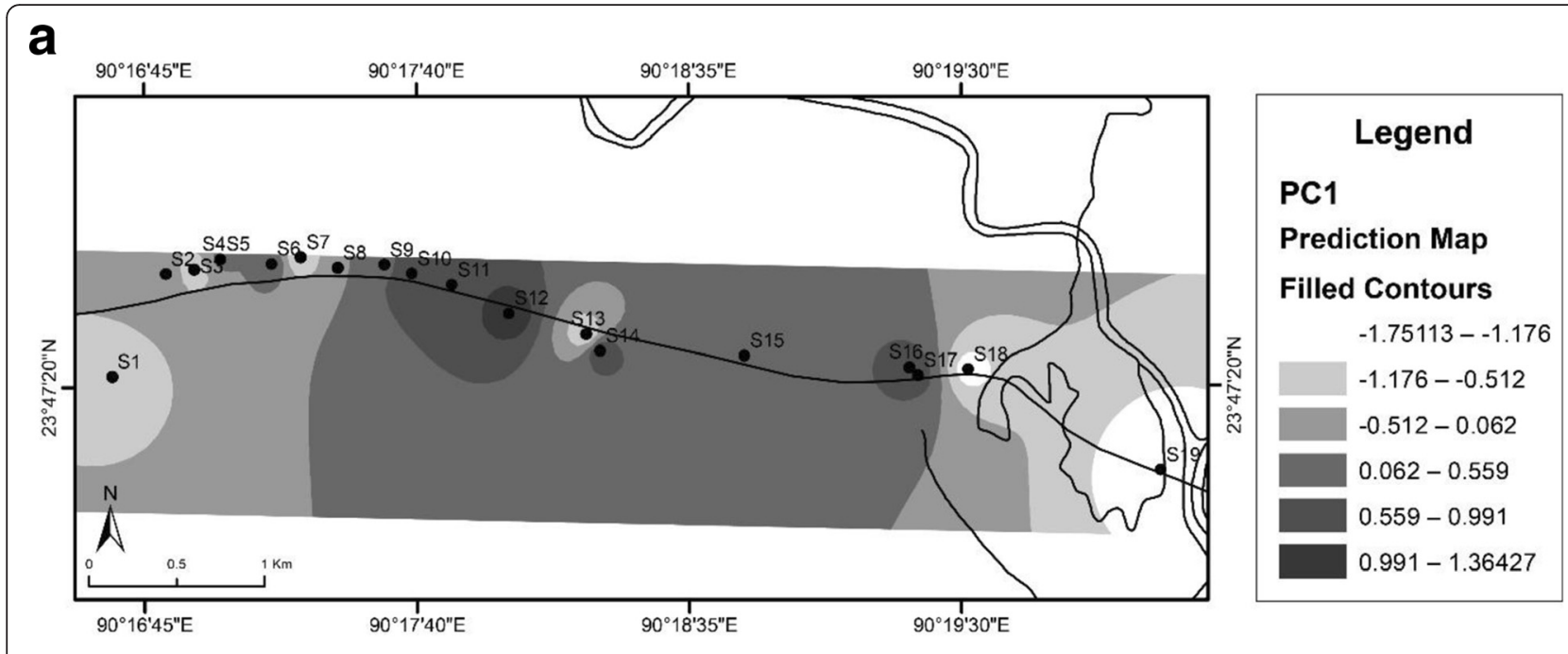

b
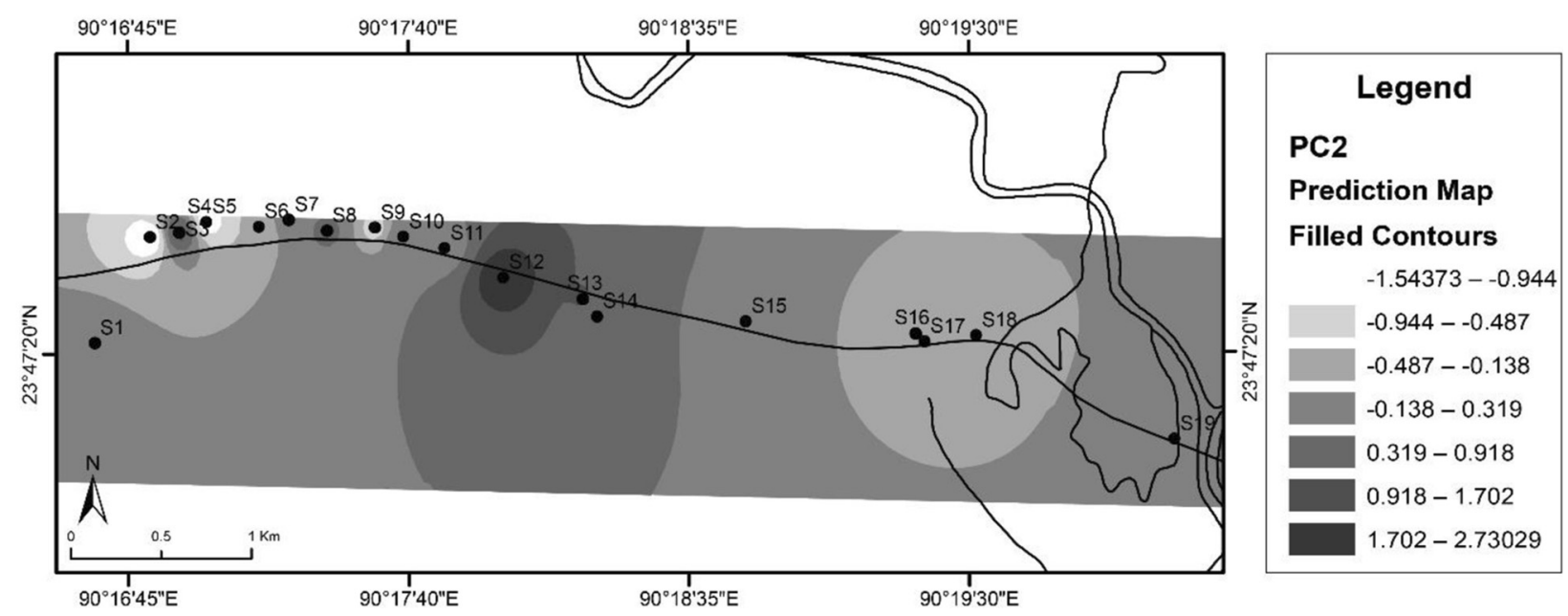

C
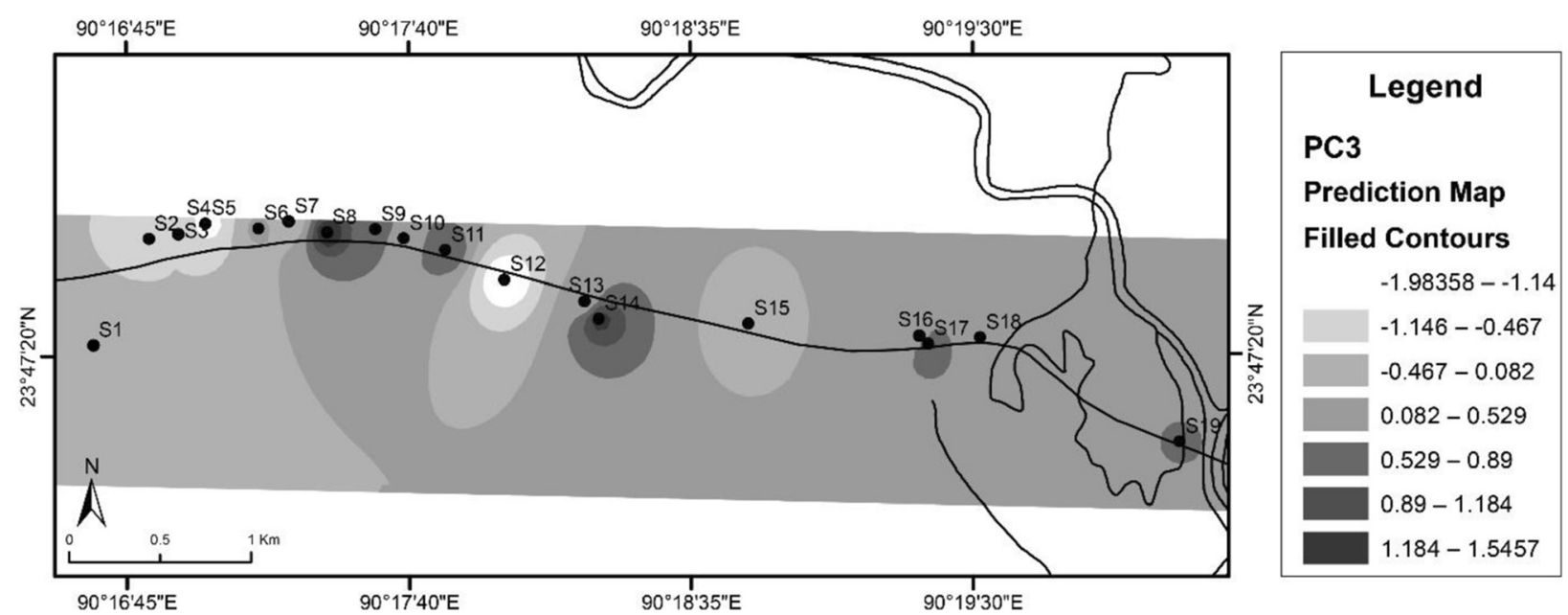

Fig. 6 Factor score map of Principle Components (PC1, PC2 and PC3) as a for PC1, b for PC2 and $\mathbf{c}$ for $\mathrm{PC} 3$ 


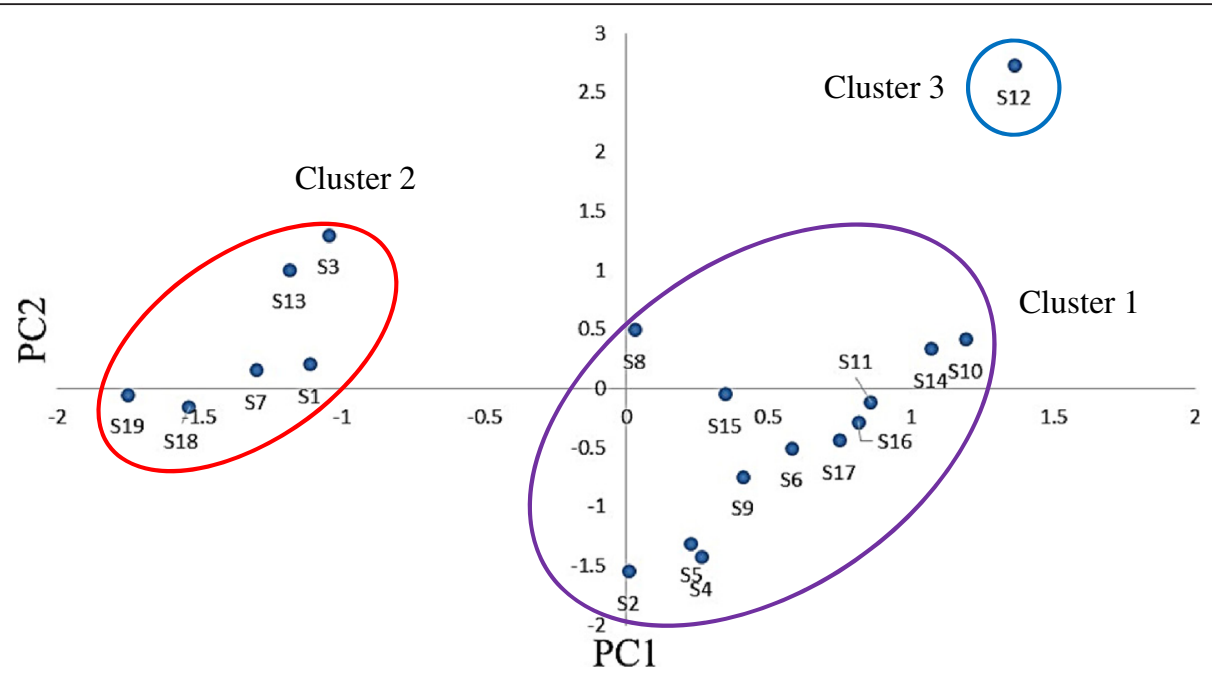

Fig. 7 PC1vs. PC2 plot of sampling site grouping

were considered. According to Liu et al. (2003), strong, moderate, and weak factor loadings range from $>0.75$, 0.75 to 0.5 , and 0.5 to 0.3 , respectively.

The first principal component (PC1) in the datasets explains $39.610 \%$ of total variance and is strongly positively loaded with $\mathrm{Fe}, \mathrm{Al}, \mathrm{Ti}$, and $\mathrm{Rb}$ and moderately positively loaded with $\mathrm{Ba}$, indicating both natural and anthropogenic sources. The dominant factor loading of $\mathrm{Fe}$ in the first PC1 strongly suggests that the origin of Fe could be associated to the local emission sources such as metallurgical plant (Mmolawa et al. 2011). Al correlates with $\mathrm{Fe}$ in weathered materials and can be an indicator of mafic rocks. Anthropogenic sources of $\mathrm{Ti}$ and $\mathrm{Rb}$ include paint pigments and glass dust, but mainly natural sources are more important than anthropogenic sources (Reimann and de Caritat 1998). Major sources of Ba include manufacture of rubber, paper, fabrics, glass, plastics, and enamels. These parameters retain high positive scores in S10, S11, S12, S14, S16, and S17 and negative scores in S1, S3, S7, S13, S18, and S19 (Table 5).

The PC2 in the datasets explains $19.020 \%$ of variance. PC2 is strongly positively loaded with $\mathrm{Ca}, \mathrm{Sr}$, and $\mathrm{P}$ and moderately negatively loaded with $\mathrm{Al}$, indicating anthropogenic sources. The long-established agricultural practice and liming are the sources of $\mathrm{Ca}$ and $\mathrm{P}$. Cement factories, fertilizers, and dust can also be regarded as anthropogenic sources of $\mathrm{Ca}$. $\mathrm{Sr}$ can be released from industrial waste, disposal of coal ash, and incinerator ash

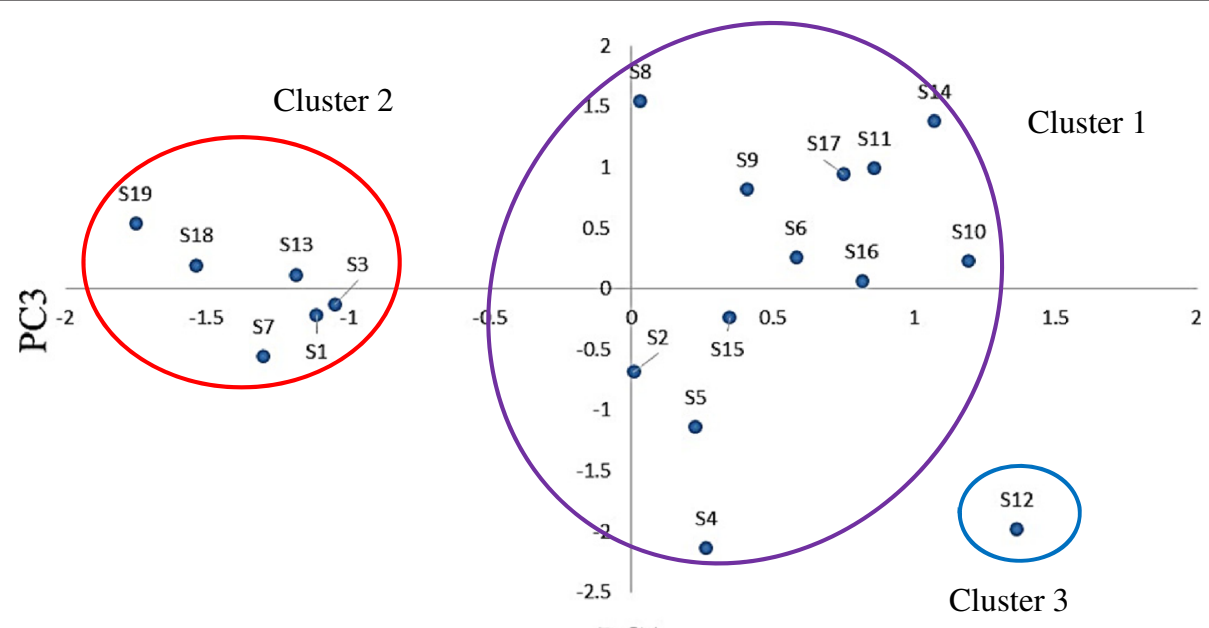

Fig. 8 PC1 vs. PC3 plot of sampling site grouping

PC1 
(Reimann and de Caritat 1998). These parameters retain high positive scores in S3, S12, and S13 and negative scores in S2, S4, S5, and S9 (Table 5).

PC3 represents $17.331 \%$ of variance and is positively loaded with $\mathrm{K}, \mathrm{Zn}$, and $\mathrm{Sn}$ and moderately negatively loaded with $\mathrm{Mn}$, indicating anthropogenic sources. $\mathrm{Zn}$ is dispersed in the environment from high traffic density (tire wear particles) (Callender and Rice, 2000). High positive loading for $\mathrm{K}$ indicated their sources related with soil parent material (Ali and Malik, 2011). Zinc is readily adsorbed by clay minerals and carbonates (Krishna and Govit 2004). Possible reason for Zn concentration being higher is due to its association with sewage pollution (Muniz et al. 2003).

$\mathrm{Sn}$ is released from waste incineration and coal and wood combustion in the surrounding Brickfield area. These parameters retain high positive scores in $\mathrm{S} 8, \mathrm{~S} 9, \mathrm{~S} 11, \mathrm{~S} 14$, and S17 and negative scores in S4, S5, and S12 (Table 5).
For all the elemental dataset, five clusters are found in the $\mathrm{PC} 1$ vs. $\mathrm{PC} 2$ plot (Fig. 4). Cluster 1 incorporates $\mathrm{Rb}$, $\mathrm{Ti}, \mathrm{Fe}$, and $\mathrm{Al}$, and cluster 2 consists of $\mathrm{K}, \mathrm{Mn}, \mathrm{Ba}$, and $\mathrm{Sn}$. Cluster 3 includes $\mathrm{Ca}, \mathrm{Sr}$, and P. Clusters 4 and 5 include $\mathrm{Zr}$ and $\mathrm{Zn}$, respectively. For the $\mathrm{PC} 1$ vs. $\mathrm{PC} 3$ plot (Fig. 5), similarly five main clusters are obtained. Cluster 4 of both plots shows similar grouping.

\section{Spatial similarities and site grouping}

Using GIS, factor score maps were generated following the IDW method for three principal components. Interpolation surfaces are created using the coordination data and site-based factor scores. The power value was set to 2; standard neighborhood was used instead of smooth neighborhood, and sector type was sector 4 with $45^{\circ}$ offset. Obtained interpolation surface explains three dominant processes in the study area. Figure $6 \mathrm{a}, \mathrm{b}$, and c represents factor score maps for $\mathrm{PC} 1, \mathrm{PC} 2$, and $\mathrm{PC}$, respectively.

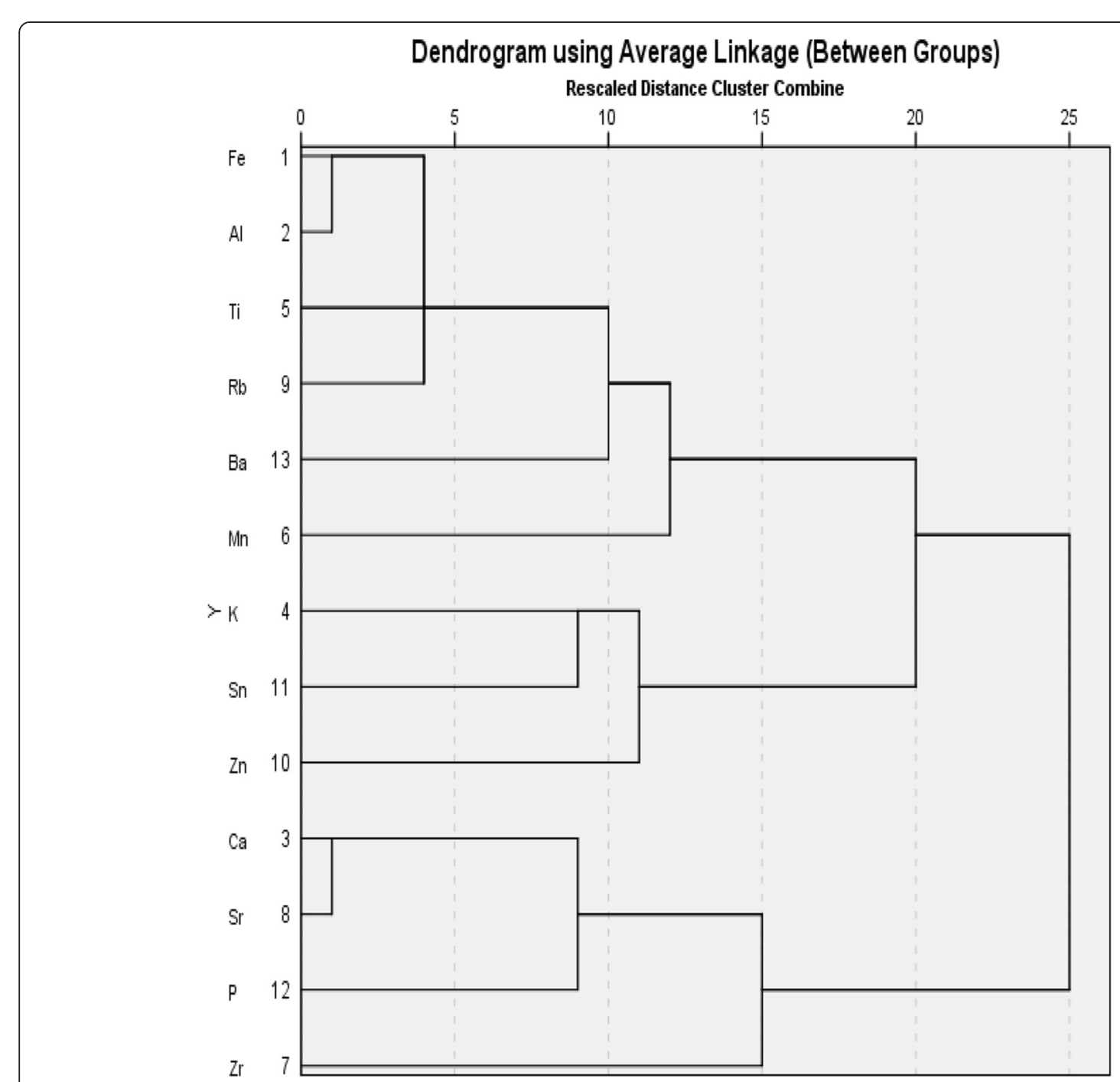

Fig. 9 Hierarchical clusters formed among analyzed metals 
Within the -1.75113 to 1.36427 range of scores, about $49.501 \%$ of the study area lies within positive factor loading, and about $50.498 \%$ of the area lies within the range of -1.75113 to 0.062 (Fig. 6a). This indicates the processes related to $\mathrm{PC} 1$. The loading of $\mathrm{PC} 1$ increases from the western to the eastern parts then decreases at the eastern side of the study area. S12, S16, and S17 show the highest positive impact of PC1.

In Fig. 6b, the factor scores of $\mathrm{PC} 2$ range from -1.54373 to 2.73029 . About $21.289 \%$ of the study area bears positive factor loading, and about $78.710 \%$ of the area has a loading in the range of -1.54373 to 0.319 . The highest positive impact of $\mathrm{PC} 2$ occurs in $\mathrm{S} 12$ which is near the Amin Bazar landfill area.

The PC3 factor score map (Fig. 6c) ranges from -1.98358 to 1.5457 . About $68.477 \%$ of the area covers the positive factor loadings. The highest positive impact of PC3 occurs in S8 and S14.
In order to identify sample site clustering, factor scores obtained from PCA are used and PC1 vs. PC2 and $\mathrm{PC} 1$ vs. $\mathrm{PC} 3$ plots are generated (Figs. 7 and 8). On the $\mathrm{PC} 1$ vs. PC2 plot, three main clusters are obtained. Cluster 1 includes S2, S4, S5, S6, S8, S9, S10, S11, S14, S15, S16, and S17. Cluster 2 contains S1, S3, S7, S13, S18, and S19. Cluster 3 contains only S12. For the PC1 vs. PC3 plot (Fig. 7), three main clusters are obtained. All the three clusters are similar to PC1 vs. PC2.

\section{CA}

CA performed on the elemental data reveals three major clusters (Fig. 9). Cluster 1 comprises $\mathrm{Fe}, \mathrm{Al}, \mathrm{Ti}, \mathrm{Rb}, \mathrm{Ba}$, and $\mathrm{Mn}$. The interrelated association among these metals shows similar positive loadings in PC1. Cluster 2 includes $\mathrm{K}, \mathrm{Sn}$, and $\mathrm{Zn}$. The interrelated association shows similar positive loadings in PC3. Cluster 3 contains $\mathrm{Ca}, \mathrm{Sr}, \mathrm{P}$, and $\mathrm{Zr}$, and its positive loadings are similar to $\mathrm{PC}$.

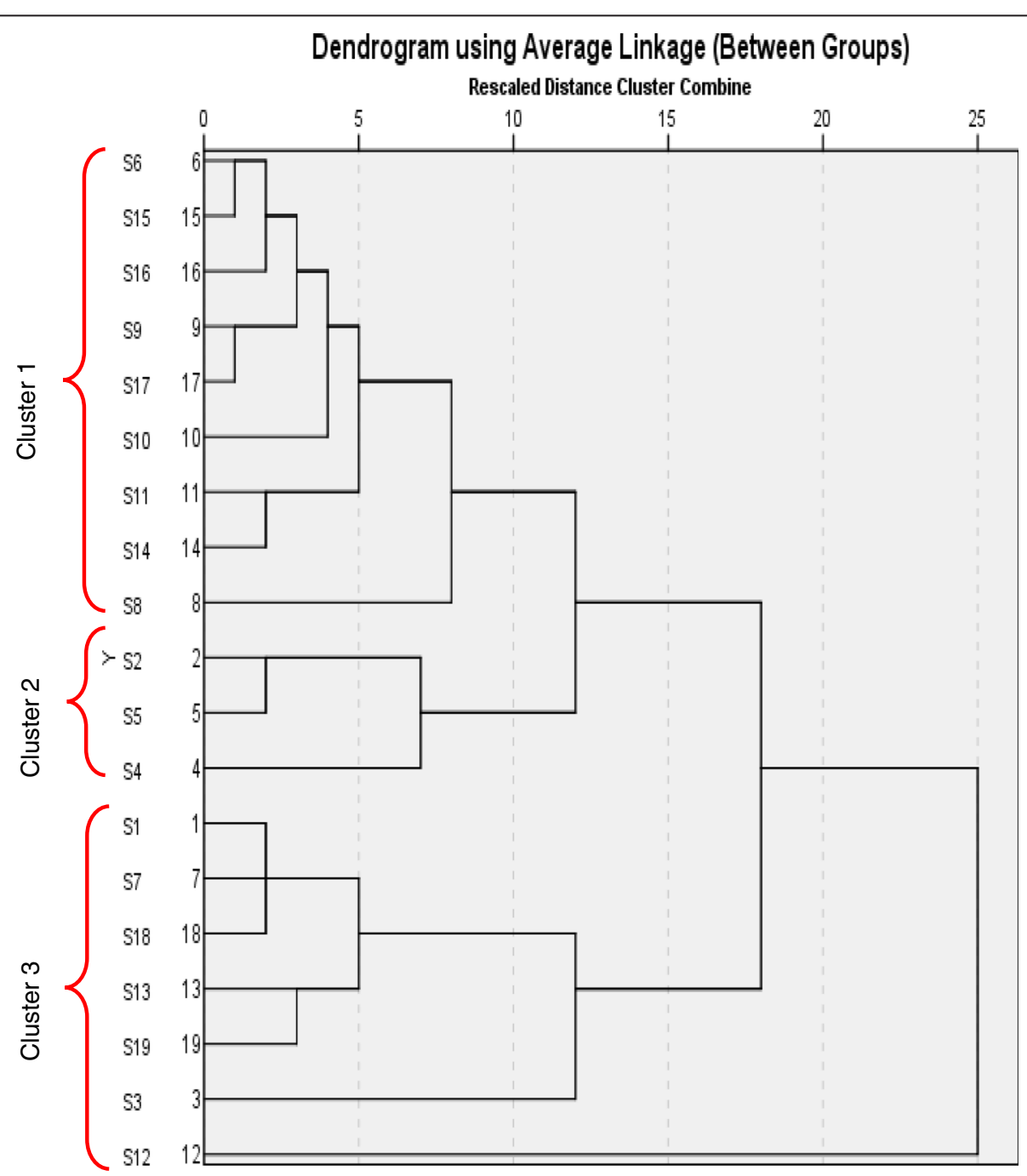

Fig. 10 Hierarchical clusters formed among sampling sites 
Spatial similarities are discovered by R-mode CA. Nineteen sampling sites form three major clusters (Fig. 10). In cluster 1, the similarities among sampling sites S6, S8, S9, S10, S11, S14, S15, S16, and S17 are also observed in the factor score map of PC3. Cluster 2 represents the similarities among sampling sites S2, S4, and S5 which are noticed in the factor score map of PC2. The same observation is found in cluster 3 which represents the similarities among sampling sites S1, S3, S7, S12, S13, S18, and S19 in the factor score map of PC1.

\section{Pearson's correlation matrix (CM)}

Pearson's CM brings out some interconnection between the parameters (Table 5). Strong positive relationship is found among $\mathrm{Fe}-\mathrm{Al}, \mathrm{Fe}-\mathrm{Ti}, \mathrm{Fe}-\mathrm{Rb}, \mathrm{Al}-\mathrm{Ca}$, and $\mathrm{Ca}-\mathrm{Sr}$ $(P<0.01)$ which is also observed in $\mathrm{PC1}$. Negative correlation is found among $\mathrm{Fe}-\mathrm{Zr}, \mathrm{Al}-\mathrm{Ca}, \mathrm{Al}-\mathrm{Zr}$, and $\mathrm{Zr}-\mathrm{Rb}(P<0.01)$ which is described in PC1 and PC2.

\section{Multivariate analysis and management implication}

PCA, FA, and CA will be excellently used in future studies to find inter-parameter associations existing between different pollutants. This data-mining technique will further help in reducing the number of pollution parameters to be tested and subsequent cost of analysis. The result of this study supports the fact that multivariate statistical methods including CA and PCA/FA can be applied to interpret complex datasets of heavy metals in soil, understand spatial variation in of heavy metals along roadside areas, and identify latent pollution sources/factors. Therefore, this evaluation study can help managers identify the main sources of pollution in different regions so as to determine their priorities for pollution minimization and source reduction. Since multivariate statistical methods are easily applied to heavy metal data, using them can be a practical approach to environmental impact assessment. The Dhaka Aricha highway is a pollution hotspot, dispersing the toxic metals in the environment. For source identification, important heavy metals, and their hotspot location, we can easily use multivariate tools for pollution source zonation and to reveal the main harbor of contamination of heavy metals in this area. In this study, for PCA, FA, and CA metal datasets, three major principal components and three major clusters were formed. Major metals like $\mathrm{Fe}, \mathrm{Rb}, \mathrm{Ti}$, and $\mathrm{Al}$ are found in $\mathrm{PC} 1$ and cluster 1. A quite similar pattern is also shown in $\mathrm{PC} 2$, cluster 2, and PC3, cluster 3. So we can easily identify the major metals in the study area and their sources. We can reduce their point and non-point sources of pollution and reduce their concentration in soil. Thus, we can easily manage or handle the pollution reduction strategy and also give priority to those sites where close monitoring is needed.

\section{Conclusions}

This work was undertaken to evaluate the surface soil state of the Hemayetpur-Gabtoli region. CF, EF, PLI, and $I_{\text {geo }}$ indicated the pollution state and their associated anthropogenic sources. $\mathrm{Zr}$ and $\mathrm{Sn}$ show high loading, and $\mathrm{Al}$ and $\mathrm{Ca}$ show low pollution load in $\mathrm{CF}, \mathrm{EF}$, and $I_{\text {geo }}$. From PCA, three major principal components were extracted which perfectly reduced the data dimension and also indicated possible anthropogenic sources. These components explain $75.961 \%$ of the total variance. From the factor score map, high positive loading is found near the Boilapur-Amin Bazar landfill site (PC1), near Boilapur (PC2), and near the Noyahati-Amin Bazar landfill site (PC3). CA formed three major clusters for both water parameters and sampling sites. This result regarding sources showed similarities among PCA and CA. The present investigation clearly indicates that the soils from freshwater reservoir are contaminated with some toxic heavy metals. Consequently, there is a dire need to reduce/regulate the anthropogenic sources of pollution in the study area.

Competing interests

The authors declare that they have no competing interests.

\section{Authors' contributions}

FA generate the idea and write the manuscript. ANMF supervised the work, MdTI analyzed the statistical part and helps in writing. NK, TAK, MdMR helped in laboratory analysis. ATMA supervises the laboratory works and helps in writing. All authors read and approved the final manuscript.

\section{Author details}

${ }^{1}$ Department of Environmental Sciences, Jahangirnagar University, Savar, Dhaka 1342, Bangladesh. ${ }^{2}$ Institute of Food Science \& Technology (IFST), Bangladesh Council of Scientific \& Industrial Research (BCSIR), Dhaka, Bangladesh.

Received: 7 October 2015 Accepted: 11 March 2016

Published online: 31 March 2016

\section{References}

Abdul-Wahab SA, Bakheit CS, Al-Alawi SM (2005) Principal component multiple regression analysis in modelling of ground-level ozone factors affecting its concentrations. Environ Model Software 20(10):1263-1271

Adyel TM, Rahman SR, Khan M, Islam N (2012) Analysis of heavy metal in electrocoagulated metal hydroxide sludge (EMHS) from the textile industry by energy dispersive X-ray fluorescence (EDXRF). Metals 2:478-487

Ali SM, Malik RN (2011) Spatial distribution of metals in top soils of Islamabad City, Pakistan. Environ Monit Assess 172:1-16

Arnason JG, Fletcher BA (2003) A 40+ year record of Cd, Hg, Pb, U deposition in soils of Patroon Reservoir, Albany County, NY, USA. Environ Pollut 123:383-391

Bretzel F, Calderisi M (2006) Metal contamination in urban soils of coastal Tuscany (Italy). Environ Monit Assess 118:319-335

Brumelis G, Lapina L, Nikodemus O, Tabors G (2000) Use of an artificial model of monitoring data to aid interpretation of principal component analysis. Environ Model Software 15(8):755-763

Callender E, Rice KC (2000) The Urban Environmental Gradient Anthropogenic influences on the spatial and temporal distributions of Lead and Zinc in sediments. Environmental Science and Technology, 34:2

Chen M, Ma LQ, Harris WG (1999) Baseline concentrations of 15 trace elements in Florida surface soils. J Environ Qual 28:1173-1181

Chowdhury MHI (2006) Urban diversity changes under globalization. A management perspective on beneficial urban development with a special reference to Dhaka megacity. Paper submitted to T.U., Berlin, Germany earth's crust. Bull Geol Soc Am 72:175-192 
Daskalakis KD, O'Connor TP (1995) Normalization elemental soil contamination in the Coastal United States. Environ Sci Technol 29:470-477

Facchinelli A, Sacchi E, Mallen L (2001) Multivariate statistical and GIS-based approach to identify heavy metal sources in soils. Environ Pollut 114:313-324

Franco-Uría A, López-Mateo C, Roca E, Fernández Marcos ML (2009) Source identification of heavy metals in pasturel by multivariate analysis in NW Spain. J Hazard Mater 165:1008-1015

Garcia R, Milla'n E (1998) Assessment of Cd, Pb and Zn contamination in roadside soils and grasses from Gipuzkoa (Spain). Chemosphere 37(8):1615-1625

Granero S, Domingo JL (2002) Levels of metals in soils of Alcala de Henares, Spain: human health risks. Environ Int 28:159-164

Han YM, Du PX, Cao JJ, Posmentier ES (2006) Multivariate analysis of heavy metal contamination in urban dusts of Xi'an, Central China. Sci Total Environ 355:176-186

Hoque MS, Moniruzzaman SM, Mahmud SMS (2007) Effectiveness of black spot treatments along Dhaka-Aricha highway. J Civil Eng (IEB) 35(2):93-104

Isaaks EH, Srivastava RM (1989) Applied geostatistics. Oxford University Press, New York, p 561

Islam MS (2014) Metropolitan government. An option for sustainable development of Dhaka Megacity. Environ Urban ASIA 51:35-48

Jayaprakash M, Urban BP, Velmurugan M, Srinivasalu S (2009) Accumulation of total trace metals due to rapid urbanization in microtidal zone of Pallikaranai marsh, South of Chennai, India. Environ Monit Assess 170:609-629

Kakulu SE, Abdullahi NK (2004) Impact of municipal solid waste on trace metal concentrations in herbage and soil samples of the Abuja municipality. Global J Environ Sci 3:65-69

Kelepertsis A, Argyraki A, Alexakis D (2006) Multivariate statistics spatial interpretation of geochemical data for assessing soil contamination by potentially toxic elements in the mining area of Stratoni, North Greece. Geochem Explor Environ Anal 6:349-355

Krishna AK, Govit PK (2004) Heavy metal contamination of soil around Pali industrial area, Rajasthan, India. Environ Geol 47:38-44

Kumru MN, Bakac M (2003) R-mode factor analysis applied to the distribution of elements in soils from the Aydin basin, Turkey. J Geochem Explor 77:81-91

Liu CW, Lin KH, Kuo YM (2003) Application of factor analysis in the assessment of groundwater quality in a Blackfoot disease area in Taiwan. Sci Total Environ 313:77-89

Liu J, Cui B, Dong S, Zhu J, Yao W (2006) Study on the effect of highway construction on photosynthetic rate of roadsides plant in longitudinal range-Gorge Region. Chinese Sci Bull 51(Supp):59-68

Love D, Hallbauer D, Amos A, Hranova R (2004) Factor analysis as a tool in groundwater quality management, two southern African case studies. Phys Chem Earth 29:1135-1143

Maitra MK, Akhter SH (2011) Neotectonics in Madhupur tract its surroundings floodplains. Dhaka Univ J Earth Environ Sci 12:83-89

Manta DS, Angelone M, Bellanca A, Neri R, Sprovieri M (2002) Heavy metals in urban soils: a case of Palermo (Sicily), Italy. Sci Total Environ 300:229-243

Mitsch WJ, Gosselink JG (1993) Wetlands, 2nd edn. Van Nostrand- Reinhold, USA

Mmolawa KM, Likuku AS, Gaboutloeloe GK (2011) Assessment of heavy metal pollution in soils along major roadside areas in Botswana. Afr J Environ Sci Technol 5(3):186-196

Muller G (1969) Index of geoaccumulation in soils of the Rhine River. Geojournal 2:108-118

Muniz P, Danulat E, Yannicellu B, Garcia-Alonso J, Medina G, Bicego MC (2003) Assessment of contamination by heavy metals and petroleumhydrocarbons in sediments of Montevideo harbor (Uruguay). Environ Int 1096:1-10

Nabuloa G, Oryem-Origa H, Diamond M (2006) Assessment of lead, cadmium, and zinc contamination of roadside soils, surface films, and vegetables in Kampala City, Uganda. Environ Res 101:42-52

Navas A, Machin J (2002) Spatial distribution of heavy metals and arsenic in soils of Aragon (northeast Spain): controlling factors and environmental implications. Appl Geochem 17:961-973

Odiette WO (1999) Environmental physiology of animals and pollution. Diversified Resources Ltd, Lagos, pp 171-85

Othman I, Al Oudat M, Al Masri MS (1997) Lead levels in roadside soils and vegetation of Damascus city. Sci Total Environ 207:43-48

Rajaram T, Das A (2008) Water pollution by industrial effluents in India discharge scenarios and case for participatory ecosystem specific local regulation. Futures 40:56-69

Raven PH, Evert RF (1976) Biology of plants, 2nd edn. Worth Publishers Inc, New York, p 544
Reimann C, de Caritat P (1998) Chemical elements in the environment. Factsheets for the Geochemist Environmental Scientist, Berlin

Rodriguez M, Rodriguez E (1982) Lead and cadmium levels in soils and plants near highways and their correlations with traffic density. Environ Pollut Ser B4:281-290

Sarbu C, Pop HF (2005) Principal component analysis versus fuzzy principal component analysis. A case study, the quality of Danube water 1985e1996. Talanta 65:1215-1220

Sezgin N, Ozcan HK, Demir G, Nemlioglu S, Bayat C (2003) Determination of heavy metal concentrations in street dusts in Istanbul E-5 highway. Environ Int 29:979-985

Sin SN, Chua H, Lo W, Ng LM (2001) Assessment of heavy metal cations in soils of Shing Mun River, Hong Kong. Environ Int 26:297-301

Singh KP, Malik A, Mohan D, Sinha S (2004) Multivariate statistical techniques for the evaluation of spatial temporal variations in water quality of Gomti River India, a case study. Water Res 38:3980-3992

Singh KP, Malik A, Sinha S, Singh VK, Murthy RC (2005a) Estimation of source of heavy metal contamination in soils of Gomti River India using principal component analysis. Water Air Soil Pollut 166:321-341

Singh KP, Malik AD, Mohan S, Sinha S, Vinod KS (2005b) Chemometric data analysis of pollutants in wastewater-a case study. Anal Chim Acta 5321:15-25

Sparks T (2000) Statistics in ecotoxicology. Wiley, Chichester

Stoffers P, Glasby GP, Wilson CJ, Davis KR, Watter P (1986) Heavy metals pollution in Wellington Harbour. New Zeal J Mar Freshw Res 20:495-512

Sultan K (2007) Distribution of metals and arsenic in soils of central Victoria (Creswick-Ballarat), Australia. Arch Environ Contam Toxicol 52:339-346

Turekian KK, Wedepohl DH (1961) Distribution of the elements in some major units of earth's crust. Bull Geol Soc Am 72:175-192

Turer DG, Maynard BJ (2003) Heavy metal contamination in highway soils. Comparison of Corpus Christi, Texas and Cincinnati. Clean Technol Environ Policy 4(4):235-245

Udosen ED, Udoessien El, Ibok UJ (1990) Evaluation of some metals in the industrial wastes from a paint industry and their environmental pollution implications. Nigerian J Technol Res 2:71-77

Usero J, Garcia A, Fraidias J, Calidad de las aguas y soilos del Litoral aluz, in, Junta de alicia, Consejeria del Medio Ambiente, Sevilla. (2000) Editorial $164 \mathrm{pp}$.

Varol M, Sen B (2012) Assessment of nutrient heavy metal contamination in surface water soils of the upper Tigris River, Turkey. Catena 92:1-10

Viard B, Pihan F, Promeyrat S, Pihan JC (2004) Integrated assessment of heavy metal ( $\mathrm{Pb}, \mathrm{Zn}, \mathrm{Cd}$ ) highway pollution: bioaccumulation in soil, Graminaceae and land snails. Chemosphere 55:1349-1359

Wang XS, Qin Y, Sang SX (2005) Accumulation and sources of heavy metals in urban topsoils: a case study from the city of Xuzhou, China. Environ Geol 48:101-107

Wang HH, Li LQ, Wu XM, Pan GX (2006) Distribution of Cu and Pb in particle size fractions of urban soils from different city zones of Nanjing, China. J Environ Sci-China 18:482-487

Ward N, Brooks RR, Roberts E, Boswell CR (1977) Heavy metal pollution from automotive emissions and its effect on roadside soils and pasture species in New Zealand. Environ Sci Technol 11:917-920

Wilcke W, Muller S, Kanchanakool N, Zech W (1998) Urban soil contamination in Bangkok: heavy metal and aluminum partitioning in topsoils. Geoderma 86:211-228

Zechmeister HG, Hohenwallner D, Hanus-IIInar A (2005) Estimation of element deposition derived from road traffic sources by using mosses. Environ Pollut 138:238-249

Zhang H, Ma D, Xie Q, Chen X (1999) An approach to studying heavy metal pollution caused by modern city development in Nanjing, China. Environ Geol 38(3):223-228

Zhang J, Liu CL (2002) Riverine composition and estuarine geochemistry of particulate metals in china-weathering features, anthropogenic impact and chemical fluxes. Estuarine, Coastal, Shelf Science, 54:1051-1070.

Zsefer P, Glasby GP, Sefer K, Pempkowiak J, Kaliszan R (1996) Heavy-metal pollution in superficial soils from the southern Baltic Sea off Poland. J Environ Sci Health 31A:2723-2754 